\title{
Is an investing institution one shareholder or a collection of separate
} funds?

Armitage, S.; Haig, A.; Hodgkinson, L.

\section{Corporate Governance: An International Review}

DOI:

$10.1111 /$ corg. 12159

Published: 04/02/2016

Peer reviewed version

Cyswllt i'r cyhoeddiad / Link to publication

Dyfyniad o'r fersiwn a gyhoeddwyd / Citation for published version (APA):

Armitage, S., Haig, A., \& Hodgkinson, L. (2016). Is an investing institution one shareholder or a collection of separate funds? Corporate Governance: An International Review.

https://doi.org/10.1111/corg.12159

\section{Hawliau Cyffredinol / General rights}

Copyright and moral rights for the publications made accessible in the public portal are retained by the authors and/or other copyright owners and it is a condition of accessing publications that users recognise and abide by the legal requirements associated with these rights.

- Users may download and print one copy of any publication from the public portal for the purpose of private study or research.

- You may not further distribute the material or use it for any profit-making activity or commercial gain

- You may freely distribute the URL identifying the publication in the public portal ?

Take down policy

This is the peer reviewed version of the following article: Is an investing institution one shareholder or a collection of separate funds?, which has been published in final form at

http://onlinelibrary.wiley.com/doi/10.1111/corg.12159/abstract. This article may be used for non-commercial purposes in accordance with Wiley Terms and Conditions for Self-Archiving.

Take down policy

If you believe that this document breaches copyright please contact us providing details, and we will remove access to the work immediately and investigate your claim. 


\title{
IS AN INVESTING INSTITUTION ONE SHAREHOLDER OR A COLLECTION OF SEPARATE FUNDS?
}

\author{
Seth Armitage ${ }^{1}$ \\ Alistair Haig ${ }^{2}$ \\ Lynn Hodgkinson ${ }^{3}$
}

Forthcoming, Corporate Governance: An International Review, 2016

${ }^{1}$ seth.armitage@ed.ac.uk, corresponding author, ${ }^{2}$ alistair.haig@ed.ac.uk, both at University of Edinburgh Business School, 29 Buccleuch Place, Edinburgh EH8 9JS

${ }^{3}$ 1.hodgkinson@bangor.ac.uk, Bangor Business School, Hen Coleg, College Road, Bangor LL57 2DG

\section{Acknowledgements}

We thank Chris Florackis (associate editor) and two referees for detailed and constructive comments, and Laurence Jones and Steven Kay for careful research assistance. We have benefited from presentations at Bangor University, the University of Wales Accounting and Finance Colloquium, and the British Accounting and Finance Association Scottish Area Conference. 


\section{Biographies of authors}

Seth Armitage is a Professor of Finance at the University of Edinburgh. His research and teaching are mainly in the area of corporate finance, including seasoned equity offers, the cost of capital, and dividend policy. His papers have been published in a number of academic journals. He is an associate editor of European Journal of Finance, and the author of The Cost of Capital: Intermediate Theory. He has served as head of accounting and finance at HeriotWatt and Edinburgh universities. Seth started his career in commercial banking in London.

Alistair Haig worked in buy-side and sell-side investment research for 15 years before joining the University of Edinburgh in 2012. Motivated by live practitioner questions and disruptions in the investment management industry, his primary focus is on how professional investors choose to procure information from external sources such as sell-side and independent research firms. This has become known as the market for investment research. In addition to teaching financial markets and institutions he remains an active member of several professional bodies (CFAUK and CISI). Alistair is a CFA charterholder with degrees from Strathclyde University (BA) and Warwick Business School (MSc).

Professor Lynn Hodgkinson was first appointed to Bangor Business School in 1987 following the completion of her PhD studies as a Research Officer at Plymouth Business School. She left Bangor to take up a senior lectureship at Liverpool University in 2002 but returned to Bangor as a senior lecturer in 2003 and became Professor of Accounting and Finance in 2006. Her recent publications include papers in British Accounting Review, Journal of Business Finance and Accounting, Journal of Banking and Finance and European Financial Management. Professor Hodgkinson is currently the Vice-Chair of the Conference of Professors of Accounting and Finance. 


\begin{abstract}
Manuscript Type. Empirical.

Research Question/Issue. The paper examines whether the fund managers in a given investing institution behave in a co-ordinated manner, in terms of their trading around the announcement of a major takeover by a company in which the institution has two or more separate holdings. Research Findings/Insights. Our data show that many institutional holdings consist of subholdings managed by separate fund managers. We find that trading around takeover announcements is co-ordinated in a majority of cases, but there is material disagreement within institutions in a substantial minority of cases, depending on how disagreement is measured. This suggests that blocks, at the level of the institution, do not always exist in the sense of being controlled by a single agent. Institutional ownership is less concentrated than it might appear to be from lists of shareholders in annual reports and databases.
\end{abstract}

Theoretical/Academic Implications. Research in corporate governance tends to assume implicitly that an institutional holding is a single block. Our findings indicate that it is not safe to make this assumption, especially in the case of larger blocks which are more likely to consist of several subholdings. Some types of research would benefit from using data at the level of the managed fund.

Practitioner/Policy Implications. There is much discussion about the merits of co-ordinated shareholder action between investing institutions, for example in the Kay Review (2012). The findings imply that there is scope for greater co-ordination within institutions as well as across institutions.

Keywords: institutional investors; blockholdings; ownership concentration; shareholder coordination; measures of agreement. 


\section{INTRODUCTION}

Principle 5 of the UK Financial Reporting Council's 2012 Stewardship Code states that 'institutional investors should be willing to act collectively with other investors where appropriate' (p. 8). The Kay Review (2012) of the investment industry highlights the potential for lack of co-ordination between fund managers, and advocates more collective action towards companies by the institutions that have shareholdings in a given company. ${ }^{1}$ Both the Stewardship Code and the Kay Review have in mind collaboration between asset-management groups. They assume, implicitly, that fund managers within a group act collectively. Our results indicate that this assumption is questionable. This suggests that there is scope for greater collective action within groups as well as across groups.

Asset-management groups as a whole are by far the most important category of shareholder in UK listed companies. However, individual groups rarely own more than $20 \%$ of a given company, and stakes of less than $10 \%$ are the norm. They therefore do not seek to achieve outright control or even a controlling stake. The fragmentation of institutional holdings is due, in part, to the advantages of holding a diversified portfolio, but it is seen as a matter for concern by the Kay Review and others. For example, Tomasic and Akinbami (2013) discuss the ability of shareholders to constrain managerial behaviour. They note that 'any individual fund manager will have spread its funds around a number of firms so that it will by itself not have sufficient shareholdings in any one firm to have much clout should it decide to place pressure upon the company' (p. 8). The problem is worse when a group's investments are divided across a number of separate funds, as is normally the case.

In the corporate governance literature, shareholders with large blocks are recognised as having an important role in monitoring and challenging management. The size of a block potentially matters to company behaviour because it affects voting power and the incentive and ability of the blockholder to have a 'voice', by having a say in such matters as strategic 
initiatives, the appointment of directors and managerial remuneration. Blockholders can also influence company managers through their trading decisions, or 'voting with their feet', especially 'exit' by selling the company's shares.

Identification of blockholdings at the level of asset-management groups is standard in the literature, and has gone unquestioned until recently. No doubt this is partly because it is groups that appear in lists of major shareholdings in annual reports and databases. To identify a block in this way, when studying corporate governance, involves an assumption that the whole of the group's holding is controlled by a single individual or team, with a single point of view. In fact group holdings often consist of two or more smaller blocks controlled by different fund managers. A question then arises about the extent to which the fund managers act collectively. If the group's holding consists of several smaller blocks controlled by people who act independently of each other, then the larger block is incorrectly identified for the purposes of research. The block does not really exist, although it might appear to exist from a list of major shareholdings.

The question we ask whether or not the fund managers in a group act in a collective manner with respect to a given investee company. Specifically, the paper examines the extent to which fund managers collectively agree on whether to increase, retain or reduce their holdings in a company following a value-relevant news release about the company. For example, if all the funds in the group increase their holdings, we infer that the fund managers in the group act collectively or at least make the same investment decision to buy. But if some funds increase their holdings, while others decrease or sell out completely, we infer that the group does not act in a unified manner. Trading of the company's shares is recognised as one of the two mechanisms by which a shareholder with a non-controlling stake can exert influence over managers. We use the announcement of a large takeover as a case of value-relevant news. To ensure the takeover is of importance, we only include takeovers where the market 
value of the target company is at least ten per cent of the value of the acquiring company.

Existing evidence is limited on the co-ordination, or otherwise, of the decisions of funds within groups. Jenkinson and Jones (2004) mention, but do not answer, this question in their study of the allocation of shares to bidders in IPOs. ${ }^{2}$ Morgan, Poulsen, Wolf and Yang (2011) study the voting behaviour of US mutual funds, on proposals made by shareholders. There are nearly 20 times more individual funds in their sample than the 94 fund families (assetmanagement groups). They find that 49 fund families co-ordinate the voting decisions of their funds, and 45 do not. Our paper on the co-ordination of trading decisions within groups complements the evidence of Morgan et. al. (2011) on co-ordination of voting within groups. Between them, the papers provide evidence on group behaviour bearing on both of the mechanisms by which non-controlling shareholders exert influence over managers.

We find high levels of agreement within groups, particularly for the sub-sample where groups have only two or three funds with holdings in a company. Sixty-nine per cent of groups in this sub-sample have at least two funds making the same trading decision. The level of agreement decreases, however, as the number of funds with holdings in a given acquiring company increases. Groups with four or more funds display co-ordination in between $42 \%$ and $68 \%$ of cases, depending on the criterion adopted for what counts as a co-ordinated trading response. We examine whether there are some groups which consistently display coordinated trading behaviour. However, none of the major groups appears to apply a strict policy of co-ordination among its fund managers. The most important of the robustness tests is to re-define small trades of less than $10 \%$ of a fund's holding as 'no change'. This increases measured agreement somewhat.

Having found that levels of agreement differ across groups, the paper explores why the fund managers within a given group might make different trading decisions. Possible reasons include differences in the investment styles of the funds within a group, the net cash flows into 
or out of each fund, and the size of the holding in relation to the size of the fund. The decisions do not appear to be linked to fund style, with the exception of index funds and venture capital trusts. Index funds trade more frequently than other styles, but in small amounts; venture capital trusts trade less frequently than other styles. Net cash flows have an impact on trading, in the manner expected, but the relative size of the holding makes no difference to whether a fund trades. We also carry out regressions to explain differences in agreement across groups, and find that agreement is negatively related to the number of funds in a group, and negatively related to the market capitalisation of the acquiring company.

Our findings suggest that governance-related trading is co-ordinated within groups in the majority of cases. But it is not safe to assume that there is co-ordination, especially in the case of larger blocks at group level which are more likely to consist of several subholdings. Institutional ownership is less concentrated than it might appear to be from lists of shareholders in annual reports and databases. The findings of Morgan et. al. (2011) on voting behaviour within groups point to the same conclusion.

Several papers study the rewarding and disciplining of managers by shareholders through their trading decisions. Edmans (2009) presents a model in which trading decisions by informed blockholders affect management by making the share price reflect information about the company more accurately. The model shows that if less-informed investors tend to be shorttermist, blockholder influence on the price will promote value-adding long-term investment by the company. The size of the block matters in the model because a larger block is assumed to provide more incentive for the blockholder to become informed. Most empirical papers on disciplining management examine trading at the level of the institution, and assume implicitly that an institution is a single shareholder. Parrino, Sias and Starks (2003) and Helwege, Intintoli and Zhang (2011) document that sales by US institutions in a firm's shares increase the probability of subsequent involuntary resignation of the CEO. A sale is measured as a reduction 
in the proportion of shares owned by investing institutions in total, or as a reduction in the number of holdings at institution level. Discontent by some fund managers who sell a company's shares within an institution may be masked if others within that institution do not share that discontent and retain their current holdings or even increase them. Examining trading decisions at the fund manager level would provide a richer measure of views towards the company.

Gallagher, Gardner and Swan (2013) examine the potential for profit from private information by identifying 'swing trade' sequences by large Australian equity funds. This is a study which does examine the impact of trades by funds rather than institutions, though it does not examine whether fund managers act collectively. The study finds that the bid-ask spread falls (the share price becomes more informative) following a swing trade, and company performance improves. The authors point out that 'governance through trading' need not require that the shareholder own a block as large as the five per cent threshold common in US research. Bharath, Jayaraman and Nagar (2013) test the view that the threat of exit by blockholders constitutes an effective disciplining mechanism. The threat is reduced if the cost of exit increases, making exit less likely. Their main result is that, after a shock which reduces (increases) market liquidity, there is a negative (positive) cross-sectional relation between Tobin's $Q$ and the proportion of shares owned by blockholders (five per cent or more). Their interpretation is that, when liquidity is lower, the threat of exit by blockholders is less, which leads to increased unease about the performance of management, and a lower valuation.

The next section explains our research method in more detail, including the calculation of the agreement scores for a given group. The group holdings in the sample companies are described next, followed by the main results on agreement. The paper then examines reasons why funds within the same group might make different trading decisions, discusses some implications of the findings, and concludes. 


\section{DATA AND RESEARCH METHOD}

We wish to investigate the extent to which the behaviour of fund managers within an asset-management group is co-ordinated, with respect to a given company, in which more than one of the group's funds has a shareholding. One way to do this is to identify an important piece of news about the company, and examine changes in fundholdings around the time the information is made public. The news item we choose is the announcement of a major takeover agreement or bid. This is the sort of announcement about which an active fund manager would be expected to have an opinion, and which might result in a decision to buy or sell shares. Moeller, Schlingemann and Stulz (2005) argue that, in some cases, a takeover announcement can prompt shareholders not only to make a judgement about the takeover itself, but also to reassess their valuations of the acquiring company as a stand-alone entity. We measure the response of a fund manager to a takeover announcement via the change in the shareholding of the relevant fund around the time of the announcement.

Large takeovers are not the only type of corporate event likely to prompt a reaction among shareholders. Other examples include changes in strategy, changes in senior management, and major issues of debt or equity. However, a large takeover is among the most far-reaching events for a company, and so if co-ordination of trading within a group does takes place, it should do so around a large takeover. We expect that the degree of intra-group coordination observed in the case of takeovers will apply to some other major corporate events, but that there are few if any types of event likely to a prompt a higher degree of co-ordination.

There are other types of blockholder for which the question about control of the block could be asked. For example, a family holding could be split between several family members or trust funds. We limit our enquiry to holdings by asset-management groups because the identities of separate funds within a group can be established relatively easily and 
unambiguously. Each managed fund will normally have its own fund manager, who has the potential to act independently of other fund managers in the group. ${ }^{3}$

To construct a sample we download, from Thomson One Banker, takeover announcements by companies registered in the UK, excluding investment vehicles and companies in the financial sector. The sample period is 1 January 2005 to 31 May 2012. To avoid small companies which are more likely to have highly illiquid shares, we exclude companies with a market capitalisation of less than $£ 20 \mathrm{~m}$ four weeks before the announcement date. To improve the likelihood that the takeover is an important event, we require that, four weeks before the announcement date, the market capitalisation of the target company must be at least $10 \%$ of the market capitalisation of the acquirer. There are 178 announcements in the sample, and the companies cover the full range of sizes (above $£ 20 \mathrm{~m}$ ) and industries.

Lists of blockholders are normally disclosed in the annual reports of companies listed on stock markets, and such lists are to be found in well-known financial databases used for research, including Datastream, Thomson One Banker, Compact Disclosure, Thomson Reuters Institutional Holdings, Compustat Annual Industrial File, and others. ${ }^{4}$ In the UK there is a longstanding regulatory requirement that the annual reports of listed companies should disclose the names of the holders of blocks of three per cent or more of any class of voting capital. In the USA, the Securities Exchange Act (1934) requires public corporations to disclose, in the proxy statement sent to shareholders before the annual general meeting, the beneficial owners of blocks of five per cent or more of a class of stock. The ultimate source of information about blockholders in both countries is the share register, which company law requires companies to maintain and make available for inspection.

To obtain holdings at fund-manager level, and to include institutional shareholdings below the three per cent threshold, we turn to data compiled by Argus Vickers, a company that specialises in providing details on holdings to professional investors and brokers. Argus 
Vickers compiles sets of three lists of holdings, by 'fund manager', by beneficial owner, and by registered owner. Fund manager here refers to any type of owner, including individuals and companies, as well as financial institutions. Holdings are recorded down to $0.1 \%$ of the shares in issue. The interval between each set of the lists is usually around three months. This interval is the time period over which we measure a change in holdings.

Argus Vickers maintains a database which enables it to match, to a large extent, beneficial owners with registered holdings for UK companies. The beneficial owner of an asset is the person with the right to the benefits of ownership. The beneficial owners of institutional holdings are identified at the level of individual managed funds, rather than the level of assetmanagement groups. This reflects the fact that control of the shares lies with the fund manager rather than the group. Appendix A provides further details about the identification and role of beneficial owners.

The data in the first list from Argus Vickers, holdings by 'fund manager', are those with which practitioners and researchers will be most familiar. They generally match the holdings of three per cent or more that are disclosed in annual reports. The second list is by beneficial owner, and this list is crucial for our research purposes. It includes lists of the holdings of the individual managed funds within each asset-management group in the first list. These holdings of individual funds are not disclosed in annual reports, nor are they available in the lists of holdings from mainstream data providers. ${ }^{5}$

For each takeover announcement, we utilise the two sets of lists that straddle the announcement date, and calculate the changes in holdings from the two sets. We hand-collect, for each company with an announcement, a list of the asset-management groups which have at least two funds with holdings in the company on one or both of the two dates for which the Argus Vickers shareholdings lists are compiled. Funds where the beneficial owner is an individual or a trust are excluded. Funds are also excluded where the name of the fund is or 
includes a description such as 'Private clients' or 'ISA [Individual Share Account] holders' 6 Holdings of custodian companies, clearing houses, stockbrokers, and execution-only companies, such as Selftrade, are excluded because they do not manage their own funds.

We consult the relevant website if in doubt about whether a 'fund manager' in the list is a genuine asset-management group. There is usually a single entry for an asset-management group in the list of holdings by fund manager. In the cases where the list records two or more entities in the same group, we treat each entity as a distinct institution, as Argus Vickers does. ${ }^{7}$

Each fundholding is assigned one of the following four mutually exclusive categories, depending on the change in the holding between the pre-announcement date and the postannouncement date:

(1) increase in an existing holding, or new holding;

(2) no change;

(3) decrease;

(4) decrease to zero.

The number of funds in each category is then recorded for a given asset-management group. If the group acts in a unified manner, we would expect the funds for which it is responsible to have a common positive reaction (increases), or one that is neutral (no change), or one that is negative (decreases) or very negative (complete disposals of holdings). If, on the other hand, a group's fund managers appear to make investment decisions independently of each other, and/or there is no apparent mechanism for arriving at a common reaction, we would expect to see diversity in the changes of fundholdings.

We measure the extent to which there are departures from agreement across the changes in each group's fundholdings. We present results for two measures. The simpler measure assumes that a fund manager's reaction to the announcement is either positive, indifferent, or negative. A positive or indifferent reaction is indicated by an increase in the relevant 
fundholding, or no change, i.e. category (1) or (2) above. A negative reaction is indicated by a decrease in the holding, or a complete disposal, i.e. category (3) or (4). We include 'no change' in the positive category because there has been no exit by the fund manager, which can be seen as tacit approval. In the literature on block trading as a governance mechanism, disciplining of management is not deemed to have occurred unless some or all of the relevant block is actually sold (e.g. Parrino et al., 2003).

A unified group will have all or most of its funds in one or the other category. Using the percentage of the funds that are positive or indifferent, \%pos, the simple agreement score for a group is given by

Simple agreement score $=$ either \%pos, if \%pos $\geq 0.5$,

$$
\text { or }(1-\% \text { pos }) \text {, if } \% \text { pos }<0.5
$$

For example, if either $80 \%$ of the funds' trades are positive, or $80 \%$ of the funds' trades are negative, the score is 0.80 . The maximum score on this measure is 1.00 . The minimum depends on the number of funds, but if the number is even, the minimum is 0.50 .

The second measure we report is more refined, in that it assumes there are four possible reactions to the announcement, given by categories (1) to (4), shown above. This measure is based on a disagreement score developed by Whitworth and Felton (1999) to help assess commonality in the reactions within small groups of people. ${ }^{8}$ Consider a group with members $i, j, \ldots N$, and with $K$ mutually exclusive options to choose from. Each member $i$ of the group chooses one option. Comparing the choice made by $i$ with the choice made by another member $j$ of the group, let

$$
\begin{aligned}
& d_{i j}=1 \text { if } j \text { chooses a different option from } i \text {, and } \\
& d_{i j}=0 \text { if } j \text { chooses the same option as } i .
\end{aligned}
$$

Then the disagreement score for $i$ in relation to the rest of the group is given by

$$
d_{i}=\frac{1}{(N-1)} \sum_{j}^{N} d_{i j}=\frac{N-N_{i}}{N-1}
$$


where $N_{i}=$ the number of other group members who choose the same option as $i . d_{i}=0$ if all group members choose the same option as $i$, and $d_{i}=1$ if all group members choose a different option from $i$. The measure of disagreement for the whole group is given by the average of the disagreement scores across the group members, Disag:

$$
\operatorname{Disag}=\frac{1}{N} \sum_{i}^{N} d_{i}=\frac{N^{2}-\sum N_{i}^{2}}{N^{2}-N}
$$

The minimum value for $D$ is 0 , which means that all group members choose the same option. The maximum value depends on the number of group members $N$ in relation to the number of options $K$. If $K \geq N$, then $\max ($ Disag $)=1$. If $K<N$, then $\max ($ Disag $)<1$, and $\max ($ Disag) decreases as $N$ grows, for a given $K$. The score of 1, i.e. for each member all the other members make a different choice, is not possible because there are not enough options, so some members must make the same choice. In our case there are four types of investment decision a fund manager can make in response to an announcement, so $K=4$. $N$, the number of funds in a group with holdings in the relevant company, is most commonly a number between 2 (the minimum possible) and 10, although larger numbers appear. The formula for $\max ($ Disag $)$ is

$$
\max (\text { Disag })=\frac{N^{2}-(K-r) a^{2}-r(a+1)^{2}}{N^{2}-N}
$$

where $a$ is the whole number of times that $K$ goes into $N$, and $r$ is the remainder multiplied by $K$. For example, if $K=4$ and $N=8$ we have $\max ($ Disag $)=48 / 56=0.86$. To enable better comparisons to be made across groups with different numbers of funds, we scale the Whitworth-Felton disagreement score by $\max ($ Disag). This means that, in all cases, the score when there is maximum possible disagreement is 1 , regardless of the number of funds.

Finally, the refined measure we report is an agreement score given by

$$
\text { Refined agreement score }=1-\operatorname{Disag} / \max (\text { Disag })
$$

This has a maximum value of 1 (rather than 0 ) for cases of complete agreement, i.e. all the funds make the same type of investment decision. ${ }^{9}$ The minimum value, representing 
maximum possible disagreement, is 0 . A weakness of the refined measure is that it takes no account of which side of the fence decisions sit. 'Increase' and 'no change' are treated as being as much of a disagreement as 'increase' and 'complete disposal'. ${ }^{10}$

\section{RESULTS}

\section{Institutional Holdings in the Sample}

This section provides brief descriptive statistics about the holdings of the assetmanagement groups in the sample. There are 1,453 observations for groups with at least two holdings in a company in the sample before the announcement. The total number of funds in the sample is 5,222 , of which 2,002 increase their existing holding, or are a new holder; 1,846 make no change, 1,128 decrease their holding, and 245 sell all of their holding. So there is diversity of reaction to the announcements; it is not the case that most funds record no change.

Insert Figure 1 about here

All the group holdings are split between at least two funds invested in the company. The mean (median) group holding after the announcement is $3.5 \%(2.5 \%)$, expressed as a percentage of the number of ordinary shares outstanding in the relevant company. The minimum holding is $0.1 \%$, the maximum $31 \%$. Figure 1 shows the numbers of holdings in each of six size categories. It can be seen that most of the group holdings, $69 \%$ of the total, are between $1 \%$ and $10 \%$ of the company's equity. Another $25 \%$ are relatively small stakes of between $0.1 \%$ and $1.0 \%$. So the phenomenon of the division of a group holding across more than one managed fund is not confined to large holdings. There are very few institutional stakes of $20 \%$ or more. 
The correlation coefficient between the size of the holding and the number of funds in the group is 0.39 , so larger holdings tend to be divided across a larger number of funds. This is not surprising, but it indicates that the question of whether a group holding can be assumed to be controlled by a single agent is more pertinent for larger stakes.

The sum of the group holdings for each company in the sample represents $27.9 \%$ (median 29.7\%) of the equity on average across the companies (min 0\%; max 66.7\%). Eighteen of the companies have no institutional holdings that qualify for our sample, because most of the shares of these companies are not held by institutional investors. Excluding these 18 companies, the group holdings in the sample are on average $31.1 \%(31.4 \%)$ of the equity. Total institutional ownership is typically much higher than the total included in our sample, because we only include group holdings which are divided between at least two funds. However, the holdings of the groups with multiple funds are still large in total, and these group holdings often account for all or many of the 'large' shareholders with at least three per cent of the equity. $^{11}$

Insert Table 1 about here

\section{Agreement Scores}

We start by presenting an example, that is typical of the results overall, to give the reader a feel for what the agreement scores mean. Table 1 shows the fund decisions by group around a takeover by Bloomsbury Publishing, and the resulting agreement scores. Consider first the simple agreement score. On this measure three of the nine groups have a score of 1.00, indicating complete agreement among their funds. The rest have at least one fund that is out of line with the majority. The group with the least agreement, Aberdeen Asset Management, has 
a score of 0.60. Aberdeen has ten funds with holdings in Bloomsbury Publishing, of which six funds' trades are positive or indifferent towards the announcement, and four are negative.

Now consider the more refined agreement score. It can be seen that this score drops sharply from 1.00 (all the funds made the same decision) as soon as there is one fund which differs. For example, Capital Group Companies has five funds with holdings, one of which increases its holding while the other four make no change. The agreement score is only 0.56 , although there is only one fund that 'disagrees'. If there are only two funds, and they make different decisions, the agreement score is 0.00 . In fact the possible values for both types of agreement score are sensitive to the number of funds for a given group, which makes it problematic to present summary statistics for the whole sample.

To alleviate this problem, we present results be levels of agreement, segregated by the number of funds per group. The levels are obvious using the simple measure. For example, if there are four or five funds in a group, the levels are: level A: full agreement, score 1.00; B: one fund out of line, score 0.75 (four funds) or 0.80 (five funds); C: two and two split, or two and three split, score 0.50 or 0.60 . The levels are less obvious using the refined measure, and a subset of these results is provided in Appendix B. Level A means that all funds make the same investment decision (out of four possible), and level B means there is just one fund out of line. Level $\mathrm{C}$ means that the group is split between two decisions, and two funds make one decision and the remaining funds the other decision. The profiles are harder to summarise for lower levels of agreement. For example, there are ten possible levels of agreement for a group with seven funds. The minimum level of agreement, level $\mathrm{J}$, is a profile across the four categories of decision with one fund in one category and two in each of the other three, that is, a profile of $1,2,2,2$. The corresponding agreement score is 0.00 . The next agreement level up, level I, has a profile of $1,1,2,3$, and a score of 0.06 . Level $\mathrm{H}$ has 2, 2, 3, and a score of 0.11 . Appendix 
B shows the profiles of outcomes for groups with between four and eight funds, for some of the agreement levels.

Insert Tables 2 and 3 about here

\section{Simple Measure of Agreement.}

Table 2 presents results for the whole sample for the simple agreement score. The table shows the proportion of the groups having each level of agreement among the group's funds, categorised by the number of funds in the group with holdings in the relevant company. Nine hundred and fourteen of the groups (63\% of the sample) have two or three holdings, and in these cases, with the simple measure, there are only two possible outcomes, agreement or disagreement. The proportion of these groups showing agreement is $69 \%$.

There are 323 groups with four or five holdings, and in these cases there are three possible outcomes or levels of agreement. Forty per cent show full agreement, 37\% partial agreement (one fund is out of line), and 23\% maximum disagreement.

For the 539 groups with at least four funds, we might feel that if one fund is out of line, there is still substantial agreement. That is, we might count both agreement levels A and B in Table 2 as evidence for unified investment decisions. On this basis, the proportion of unified groups ranges from $77 \%$ for those with four or five funds, to $30 \%$ for those with 12 to 18 funds. Overall, 34\% of groups with at least four funds show agreement level A and 34\% show level B (not tabulated).

\section{Refined Measure of Agreement.}


Table 3 presents the percentage of groups in each category using the refined agreement score. For groups of all sizes by number of funds, the highest proportions tend to be at agreement levels A and B but there is a wide range of outcomes. There are only two possible scores for the 617 groups with two funds, and $61 \%$ have funds in agreement. There are three possible scores for the 297 groups with three funds, complete agreement (level A), one fund differing from the other two (B), or all three in disagreement (C). Thirty-nine per cent of groups are at level A, $49 \%$ at B, and $12 \%$ at C.

For groups with four or more funds, there is more scope for disagreement under the refined measure. But agreement levels $\mathrm{A}$ and $\mathrm{B}$ have a similar interpretation as above. Seventeen per cent of groups with four or more funds are at level A and 25\% at level B (not tabulated). So, using the refined measure, $42 \%$ of groups with four or more funds are considered to be unified funds, compared with $68 \%$ under the simpler measure. We note that, because of the positive correlation between the size of a group holding and the number of fundholdings, groups with larger stakes tend to show more disagreement. In other words, treating larger groups as a single block is problematic.

Insert Table 4 about here 


\section{Are Asset-management Groups Unified?}

A pertinent question is whether there are some asset-management groups that make a point of acting in a unified manner. Are there groups in which all or most of the funds usually show the same category of response? Table 4 provides evidence on this question. The 58 groups with at least five entries in the sample are listed, along with the proportion of the entries for each group showing agreement level A using the simple agreement measure. The table shows that there is wide variation in the proportions, from $100 \%$ (the group shows full agreement towards all the companies in which it has at least two holdings), to $17 \%$. Unfortunately the groups with relatively high proportions of full-agreement outcomes, of $90 \%$ or more, tend to be the ones with low numbers of entries in the sample. This makes it hard to say whether the high incidence of agreement for these groups arises by chance or as a result of a deliberate policy. The mean proportion of entries with full agreement is $70 \%$ for the 37 groups with fewer than 20 entries, compared with $50 \%$ for the 21 groups with 20 or more entries (not tabulated). Among groups with 20 or more entries, the most unified group has $71 \%$ of entries with full agreement. This is probably not a high enough proportion to be convincing evidence of a deliberate policy of agreement in the relevant group.

Our findings based on trading behaviour can be compared with the findings of Morgan et al. (2011) for families of US mutual funds, who examine voting behaviour on proposals by shareholders. ${ }^{12}$ The measure of Morgan et. al. for whether voting is co-ordinated is a simple score of one or zero, depending on whether voting across the funds in a family is unanimous or not (with abstention counted as a vote against). They find that just over half the fund families appear to co-ordinate the voting of their funds: their funds display unanimity in $100 \%$ of the votes in which they have at least two funds participating. The remaining families display a range of proportions of votes with unanimity across their funds. 
We do not find clear evidence of co-ordination for any of the asset-management groups with sizable numbers of holdings. Possible reasons for the difference in findings include (i) groups display more co-ordination across their funds in voting than in trading behaviour; (ii) some of the changes in shareholdings we observe are not in response to the takeover announcement (but see below); (iii) our sample consists of a mixture of types of institution, many of which are not mutual-fund families.

\section{Robustness Checks}

This section reports the results of five robustness/sensitivity checks. Our main check is to apply a filter onto what counts as a change in a fundholding. The filter we apply is that changes in existing fundholdings of less than $10 \%$, up or or down, are categorised as 'no change' rather than 'increase' or 'decrease'. The purpose of the filter is to exclude trading by funds that might have arisen for reasons not connected with the fund manager's reaction to news of the takeover. This is an important test as small trades in relation to the size of the fundholding are more likely than large trades to be due to cash inflows or outflows from the fund, or rebalancing of the portfolio, or trades that are called for by the investment style of the fund. With the simple measure, funds which have a decrease of less than $10 \%$ are now included in the 'positive or indifferent' category. This likely to increase the measured agreement across funds because, before applying the filter, there are more funds which are 'positive or indifferent' than funds which are 'negative'. With the refined measure, the filter is also likely to increase the measured agreement. The number of funds in the 'no change' category increases, and groups where all or most of the disagreements arise from some combination of small buy(s), no change, and small sell(s), will show more agreement. 
Tables 5 and 6 about here

Table 5 presents the results for the simple agreement measure, after applying the filter. For groups with two or three holdings, the proportion showing agreement rises from $69 \%$ to $78 \%$. For groups with four or five holdings, the proportion showing full agreement (level A) rises from $40 \%$ to $58 \%$. For all groups with at least four funds, $50 \%$ show agreement level A and $30 \%$ show level B with the filter (not tabulated), compared with $34 \%$ at A and $34 \%$ at B without the filter.

The results for the more refined measure in Table 6 show somewhat smaller increases. Full agreement rises from 54\% to 59\% for groups with two or three funds. For groups with four or more funds, full or almost full agreement (levels A or B) rises from $42 \%$ to $53 \%$. Across both measures, the proportion of groups with unified funds is between $53 \%$ and $80 \%$, after removing the impact of small trades. So the qualitative conclusion, of agreement in the majority of groups but disagreement in a substantial minority, does not change.

Second, we run the main analysis excluding index funds, of which there are 426 in the sample. We do this for two reasons. The first is evidence, presented in the next section, that index funds trade more than other funds, and so index funds could contribute to disagreement within groups. Second, an index fund should not have a deliberate role in influencing a company's management through trading, and so arguably index funds should be excluded in measuring agreement within a group in response to a takeover. If there is a group-wide trading response to an announcement, presumably any index funds in the group would not be part of that response, and might trade differently to fulfil its index-tracking remit. On the other hand, 
existing studies on governance involving blockholders or ownership structure do not exclude index funds.

Insert Table 7 about here

Table 7 presents abbreviated results for this and the remaining two robustness tests. ${ }^{13}$ The table concentrates on the proportion of groups with full agreement, for groups with two or three funds, and full or almost full agreement (levels A or B), for groups with four or more funds. We find that excluding index funds makes almost no difference to the results. This is partly because index funds are not scattered around the groups. Almost all those in the sample are managed by one of the following groups: Barclays, Blackrock, HSBC, Legal and General (with the largest number), Royal London, Scottish Widows, and Vanguard. This means that index holdings tend to be clustered, with two or more in one group. The clustering reduces the potential impact of index funds on the agreement scores of the full sample of groups.

Third, we exclude funds with no change in their holding, so that we only consider funds where the fund manager has taken some action. This exclusion is to allow for the view that 'no change' does not constitute a decision at all, and that we should be interested in the level of agreement among funds which do make a decision to trade. The exclusion makes little difference using the simple measure. Removing funds with no change has an impact on the results using the refined measure, as it reduces the number of response categories from four to three, and hence it reduces the scope for possible disagreement. With two or three funds, the proportion showing agreement rises from $54 \%$ to $59 \%$. With four or more funds, the proportion at agreement level $\mathrm{A}$ or $\mathrm{B}$ shows a large increase, from $42 \%$ to $65 \%$. This difference is 
significant at the $1 \%$ level $(z$-score $=6.25)$. But disagreement remains in a substantial minority of groups.

The fourth robustness test examines the subsample of the largest takeovers in relation to the size of the acquirer, because there might be more reaction by shareholders to large takeovers. To implement this test, we include only announcements of takeovers where the amount to be paid is at least $30 \%$ (instead of 10\%) of the market capitalisation of the acquirer one month before the announcement. This reduces the sample from 178 to 83 announcements, with 2,399 holdings spread among 686 asset-management groups. The results for this subsample are similar to the results for the full sample. Using the simple score, the proportion of groups with four or more funds which show agreement levels A or B is 67\%, compared with $68 \%$ for the full sample. Using the refined score, the proportion of such funds which show agreement levels A or B is $42 \%$, which is the same proportion as in the full sample. So the findings do not differ when only large takeovers are included.

Finally, we investigate whether the results differ according to the market reaction to the takeover announcement. It is possible that the fund managers in a group tend to co-ordinate their trading more if the market views the takeover either as adding value, or as destroying value. We calculate the abnormal return (AR) around each announcement, and split the sample according to whether the AR is positive or negative. ${ }^{14}$ The results show that a positive reaction is associated with a little more agreement. Using the simple measure, $71 \%(66 \%)$ of groups with two or three funds show full agreement if the reaction is positive (negative), and for groups with four or more funds, $71 \%(65 \%)$ show agreement at levels A or B. However, these differences are not statistically significant. Using the refined measure, $46 \%$ of groups with four or more funds show agreement at levels A or B if the reaction is positive, compared with $36 \%$ if it is negative, and this difference is significant at the $5 \%$ level $(z$-score $=2.22)$. 


\section{POSSIBLE EXPLANATIONS FOR TRADING DECISIONS AROUND TAKEOVERS}

The evidence so far suggests that in a large minority of cases asset-management groups differ in their trading across the funds in a given group. This section examines some possible reasons for why differences in trading are observed. The reasons examined are the styles of funds, the net cash flows of funds around the time of the announcement, and the size of the fund's holding in the company as a proportion of the fund. We also examine funds which have the same manager, and present results of regressions which attempt to explain the differences in agreement across groups.

Fund styles. One potential reason for different trading decisions is that the investment styles of funds affect the decisions around a takeover, and that the group contains funds with more than one style. We identify fund styles with the help of classifications in the Morningstar Direct database, which is widely used by investment practitioners and academics. We go through each fund in the sample and assign it to one of the following categories: (i) index, (ii) value, (iii) growth, (iv) venture capital trust (VCT), (v) neutral, (vi) unidentified. Index, value, growth, and neutral are styles as determined by Morningstar. The value, growth or neutral designations for a fund are inferred from the styles of the shares held by the fund. Each share is given a style by Morningstar based on projected earnings, four historic multiples (price/book ratio, price/sales, price/cash flow, and dividend yield), and four historic growth measures (growth in: sales, earnings per share, cash flow, and book value). We record the style for the month of the announcement, or if not reported, for the most recent of the preceding six months. ${ }^{15}$ We count pension funds with 'balanced', 'managed', or 'with profits' in the name as neutral funds. In addition to the Morningstar classifications, we create a VCT category based on the names of funds. VCTs are relatively long-term investors which might be less likely to trade. Our 'unidentified' category consists of funds which are not given any of the above classifications, or for which there are no Morningstar data. 
We test for systematic differences in trading behaviour across the categories. For example, it might be that a higher proportion of growth funds increase their holdings than value funds. If there are such differences, a reason for disagreement within a group with different styles of fund could be the effect of the styles on trading. Table 8 presents the results. Seventyeight per cent of the funds are either neutral or unclassified. This immediately suggests that differences in fund style are unlikely to be the major reason for disagreement within a group. But style could make a difference for the remaining funds, and, in particular, could explain departures from full and almost-full agreement. Panel A of Table 8 shows the proportion of funds that traded around the announcement, by style of fund, before and after applying the $10 \%$ filter (i.e. a trade has to be at least $10 \%$ of the holding to count as a trade). The proportion of funds that traded is similar at around $62 \%$, or around $46 \%$ after the filter, for all the styles except index and VCT. Seventy-seven per cent of the index funds trade, which perhaps is surprising given that they are passive funds. The proportion drops to $36 \%$ after the filter, indicating that over half the trades of index funds are small and probably reflect minor adjustments called for by the index-matching algorithm. The VCT proportion that traded is comparatively low at $30 \%$ before the filter and $22 \%$ after. This is consistent with the role of VCT funds as long-term investors.

Panel B shows the proportions of each style of fund that made each of the four possible trading decisions. There is little economic difference in the proportions across the styles, with the exceptions of index and VCT funds. A significantly higher proportion of index funds, compared with non-index funds, increase their holdings before the filter ( $z$-score for difference 
$=6.81)$, and a significantly higher proportion show no change after the filter $(z$-score $=4.22)$. A significantly higher proportion of VCT funds show no change both before and after the filter ( $z$-scores $=9.67$ and 6.73, respectively). The behaviour of index and VCT funds could be a reason for disagreement, as their behaviour differs from that of other styles. However, the impact of index funds on the main results is minor (Table 7). ${ }^{16}$ There are only 178 VCT funds in the sample, and they are concentrated in certain companies, so their contribution to disagreement in the full sample is also minor.

We find few differences in either the incidence or direction of trading by style of fund, in response to takeover announcements. It remains possible that there is a tendency for the styles to lead to differing decisions by fund managers for each takeover, without this resulting in differences by style in the direction of trading across all takeovers. To investigate this, we focus on the two styles which might be expected to differ most in their decisions, namely value and growth. Do value and growth funds tend to trade in different directions? We identify all cases with (i) at least two holdings of value funds in the same company, or (ii) at least two holdings of growth funds, or (iii) at least one holding of each style. Companies with only one value or growth holding in total are ignored. We then record whether there is full agreement, using the simple measure, among (i) the value funds, (ii) the growth funds, and (iii) across the two styles of fund. Agreement across the styles is possible when there is one of each style, but it is not possible when there is no entry for one of the styles, or when there is disagreement within one of the styles. The outcome for (i), (ii) and (iii) is either 'agreement' or 'no agreement' or 'agreement not possible'.

For example, suppose a company has three holdings of value funds, two of which are 'buy/no change' and one is 'sell', and one growth fund which is 'buy/no change'. We record (i) no agreement for the value funds, (ii) agreement for the growth fund not possible, and (iii) cross-style agreement not possible (no agreement within the value funds). Had the three value 
funds all been 'buy/no change', the outcomes would be (i) agreement for the value funds, (ii) agreement for the growth fund not possible, (iii) agreement across the styles.

There are 95 companies which meet the criteria. Of these, 39 have either value-fund or growth-fund holdings, but not both. Of the 56 companies with holdings of both styles, crossstyle agreement is impossible in 30 (24 after the filter) because of lack of agreement within one or both of the styles. This leaves 26 (32) cases with the possibility of cross-style agreement. We find that there is cross-style agreement in $81 \%(88 \%)$ of these cases. This result suggests that there is no tendency for style to cause the managers of value and growth funds to reach different decisions. In fact the reverse seems to be true.

The analysis also enables agreement within the two styles to be measured. There is somewhat more agreement within value funds than within growth funds. Sixty-two per cent of the value funds within a given group ( $72 \%$ after the filter) show full agreement, compared with $51 \%(59 \%)$ of growth funds. However, the differences in agreement are not statistically significant $(z$-scores $=1.23$ and 1.45 , respectively) .

The conclusion from the results on fund style is that there is no evidence that differences in style can help explain differences in trading decisions across funds in a given group. The only possible exceptions to this are index and VCT funds.

Net cash flows. A second possible reason for differing trading decisions is that funds have differing net cash flows around the time of the announcement. We expect that a fund receiving an inflow (outflow) is more likely to increase (decrease) its holding, and that the impact of the cash flow is positively related to the size of the flow as a proportion of the value of the fund. To implement this test, we take the cumulative net cash flow for each fund for the months which cover the period over which the change in the fund's holding is measured (this period includes the date of the takeover announcement). We express the cumulative net cash flow as a proportion of the total value of the fund at the start of the period. 
The data on monthly fund values and net cash flows are from Morningstar. We believe these data to be the best that are publicly available. But there are no data for many funds, or the fund name does not correspond unambiguously to a fund name in Morningstar. In other cases the values or net cash flows are missing for the crucial months around the announcement date. In addition, Morningstar collects data from more than one source, and the sources are sometimes not consistent with each other. One reason is that some funds have more than one class of share or unit, and a given source might not include all the classes. To reduce the impact of potential data errors, we discard values in cases where a holding exceeds $20 \%$ of the value of the fund, on suspicion that the fund value is too low. This reduces the sample of fund values from 872 to 850 . The sample of funds with both a value, and cash flows for all the relevant months, is 772 .

Insert Table 9 about here

Table 9 shows the proportions of funds with no trade, and with an increased or new holding, for funds partitioned by positive and negative net cash flows. The cash flows make a clear difference to trading behaviour, and the difference becomes more pronounced for larger flows in relation to fund value. The larger the flow, the more likely a fund is to trade in the direction of the flow. For the full sample the proportion with an increased/new holding is $47 \%$ $(38 \%)$ for funds with a positive (negative) flow ( $z$-score for difference $=2.54$ ). The difference rises to $58 \%$ versus $28 \%$, for the subsample of funds where the flow is at least $10 \%$ of fund value $(z$-score $=3.00)$. The results after applying the $10 \%$ filter show a similar pattern. We conclude that a fund's cash flow position makes a material difference to its trading behaviour, in the manner to be expected. 
Relative size of holding. The third factor we examine is the size of the holding in the company in relation to the size of the fund. It is possible that the attention a fund manager pays to a company, and the likelihood that she will trade on news about it, are positively related to the company's importance in her fund's portfolio. We therefore divide the value of the holding as at the first shareholding date by the value of the fund at the start of the relevant month. We partition the funds by value of holding/value of fund and calculate the proportion of funds in each subsample which do not trade. For this test we exclude funds where the initial holding is zero, as all these funds traded (they bought shares in the company). The sample for the test is 691 funds. The results (not tabulated) show no relation between the relative size of the holding and the incidence of trading, for holdings which are between (just above) zero and $4.0 \%$ of the fund. For example, $45 \%$ (44\%) of funds where the holding is less than $0.5 \%$ (more than $4.0 \%$ ) of the fund do not trade. Thus, there is no evidence that the importance of the holding in the fund is a factor which affects the decision to trade. ${ }^{17}$

Funds with the same manager. The Morningstar data include the names of some of the fund managers. This enables us to examine cases where two or more funds in the same assetmanagement group have the same manager, or have a manager in common if there is more than one manager. If a manager makes a different trading decision regarding the same takeover announcement, it suggests at least one of the trades is motivated by reasons other than the manager's view of the company. We identify 121 cases where two or three funds in a group share the same manager. In $78 \%$ of these cases the funds are in agreement (simple measure). This compares with $69 \%$ in the full sample of two or three funds in a group. So agreement is more likely in cases where we know the funds share a common manager, as might be expected. However, it is not so unusual for the same manager to make different trading decisions for her funds about the same company. This is evidence on the extent to which funds trade for reasons other than the view of the manager about the company. Examples of such reasons, beyond 
those already considered, are differences across funds in mandate restrictions (regarding size of investee company or risk or exposure to a single company), investment horizon, and exposure to the relevant sector.

Multivariate analysis of agreement. It is natural to wish to explain differences in levels of agreement across groups. Unfortunately there are difficulties in trying to do so. We cannot use either agreement score as the dependent variable, because both scores are affected by the number of funds in the group, as well as by the amount of agreement. Converting the scores to an ordinal measure (1 for level A, 2 for B, etc.) does not entirely solve the problem. A group with two funds could only have a score of 1 or 2 , whereas a group with six funds could have a score between 1 and 4 (simple measure). But a score of 2 for a group with two funds does not necessarily imply less disagreement than a score of 4 for a group with six funds. More problematic is a lack of data for explanatory variables. If we had data for all funds on style, cash flows, values, and manager, we could construct variables to measure 'divergence of style', or 'divergence of cash flows' for each group, which could then be used as explanatory variables. But there are almost no groups for which we have such data for all the funds. We know there will be at least one omitted variable with explanatory power, namely the net cash flows to the funds.

For the dependent variable, we focus on agreement or near-agreement, as in several places above. We construct a binary variable in which groups with full agreement receive a score of one, and zero otherwise. Our explanatory variables are the number of funds in the group (Nfunds), the size of the target company in relation to the market capitalisation of the acquiring company (Relbidsize), the three-day market-adjusted return on announcement (Mreaction), and the natural log of the market capitalisation of the acquiring company (Mcap). We expect the coefficients to be: negative for Nfunds, because a larger number of funds gives more scope for disagreement; positive for Mreaction, given the results in Table 7; negative for 
Mcap, because the shares of a larger company are less expensive to trade. We do not have a prior belief about Relbidsize; a larger takeover by an investee company might provoke more disagreement among fund managers, but equally it might make a co-ordinated trading response by the group more likely. The largest of the cross-correlations between the explanatory variables is only 0.09 , so collinearity is not a problem.

Insert Table 10 about here

Table 10 presents four sets of logit results, for the binary agreement variable constructed from the simple and refined measure, before and after the $10 \%$ filter. Nfunds is the most significant variable: a larger number of funds in the group implies a greater likelihood of disagreement. Mcap also has the expected sign and is consistently significant at the $1 \%$ level. A larger company implies a greater likelihood of disagreement. We are a little surprised by the explanatory power of Mcap. It does not arise from correlation with Nfunds, which is low (0.05). Mreaction has the expected positive sign but is not reliably significant. Relbidsize is never significant and does not have a consistent sign.

This section has searched for reasons why fund managers in the same group make different trading decisions, based on characteristics of their funds. The approach will draw a blank if the main reason for different decisions is in fact disagreement across the managers in their views of the company/takeover. We believe that the reasons for different trading decisions are a mixture of fund-specific factors, and disagreement in managers' views. We have identified one fund-specific factor, net cash flows, which has a clear impact on trading. Doubtless there are others which can affect a fund's trading. To the extent that there are reasons for differences in trading that are other than differences in the managers' views, there could be 
more agreement among the managers than their trading activity implies. The group might act with a single voice when it comes to voting of the shares, despite the different trading decisions.

\section{IMPLICATIONS OF THE FINDINGS}

Co-ordination among shareholders. Domestic and foreign investing institutions own the bulk of the shares of UK companies. It is common to observe an ownership structure which includes several blockholders with between three and 20 per cent of shares, where the holders are mainly or entirely institutions, as our shareholdings data show. This ownership structure appears to offer opportunities for voting and other influence to be applied to the companies, by means of co-ordinated activity across the relevant blockholding institutions. Institutional investors have been criticised as being too passive in their dealings with the companies they own shares in, although not everyone agrees that activism is desirable or effective (see the discussion in Becht et. al., 2008). Academic studies tend to find little or no evidence of a corporate governance role for institutions with respect to UK companies (for example, Faccio and Lasfer, 2000; Crespi-Cladera and Renneboog, 2003). On the other hand, Crespi and Renneboog (2010) find a positive relation between executive turnover and the presence of shareholder combinations with high potential voting power acting in coalition. There seems to be more institutional activism in the USA, as suggested, for example, by the survey of professional investors in McCahery, Sautner, and Starks (2015).

The Kay Review (2012) on the UK investment industry offers a statement of good practice for asset managers. This includes the recommendation that they 'should be prepared to act collectively to improve the performance of their investee companies' (p. 53). Our findings suggest that there is scope for greater collective action within the institution, as well as between institutions (or between managers in different institutions). The task of coordination, and the free-rider problem associated with dispersed holdings, are harder than they 
might appear from consideration of a conventional list of the larger shareholders in a company, which records holdings at the level of institutions. Similarly, the presence over a long period of a given institution on a company's share register could give a misleading impression about the stability and long-term nature of the holding. The holding could be controlled by several separate fund managers. Each of the funds may not always hold shares continuously in the company, and the investment horizons of the fund managers may be shorter than would be apparent from the length of time the institution, as opposed to a given fund in the institution, holds shares in the company.

Related evidence on the difficulty of co-ordinated activism is provided by the study of Becht et. al. (2009) on the Hermes UK Focus Fund (HUKFF). This fund was set up in order to buy stakes of a few per cent in UK companies where HUKFF believed that shareholder pressure could be applied that would result in increased market value. HUKFF was part of the Hermes Group, which manages two large pension funds. Although HUKFF believed its activism was beneficial - and its performance as documented in the paper supports this belief - it appears to have acted independently of other managed funds in the Hermes Group. Its main method of intervention was direct, discreet, communication with the senior executives in the company, for which a holding of a few per cent was sufficient. It usually contacted other shareholders to solicit support, but this seldom resulted in a joint letter or meeting with the company.

Ownership concentration. It is common to measure concentration by the proportion of shares owned by blockholders (5\% or more in the USA; $3 \%$ or more in the UK), or by the proportion owned by the largest single shareholder (see the review by Holderness, 2009). The interest in such measures derives in large part from studies of links between concentration and aspects of corporate governance, disclosure, and firm performance. Our findings suggest that measures of concentration, used to date, materially exaggerate the degree of effective concentration, because they assume that institutional holdings are single blocks. Studies could 
check or enhance their findings if they use data at the level of managed funds. For example, Sabherwal and Smith (2008) report a negative relation between the number of analysts and the level of concentration of outside ownership, arguing that in-house monitoring by institutions substitutes for analyst monitoring. It is plausible that the employment of an in-house analyst to cover a particular firm is often triggered by a request by a fund manager in the institution with a large fundholding in the firm. If so, there might be a stronger negative relation between the number of analysts and the size of the largest stake per institution, than between the number of analysts and the total holding per institution.

Investment horizon. Another strand in the literature argues that investing institutions differ with respect to their investment horizon, i.e. the average length of time over which the institution holds shares in a given company, and that companies also differ with respect to the average investment horizon of their shareholders. Several studies examine the impact of investment horizon on aspects of company behaviour and market phenomena such as dividend policy, the frequency of takeovers by the company, and the liquidity of its shares. The studies assume that institutions have investment horizons, and they measure differences in horizon at the level of the institution (for example, Gaspar et al., 2012, and Hovakimian and Li, 2010, for the impact of horizon on dividend payout). But it only makes sense to think of an institution as having an investment horizon to the extent that its fund managers have a common horizon. In reality, there will be heterogeneity in the horizons across managers within a given institution. If horizons were measured at the level of managed funds, the tests would be more powerful.

We are not suggesting that the findings of previous studies that use measures of concentration or investment horizon will necessarily be incorrect. Many of the largest blockholders, who have most potential impact on firm behaviour, are not institutional, especially outside the UK and a few other institutionally dominated stock markets. Many institutional blocks are held in one fund, or in two or three funds. Co-ordination presumably is 
easier between a small number of funds, which indeed is what we find. However, we suggest that certain types of study should at least include, as a robustness check, data on large shareholders in which institutional holdings are measured at the level of individual funds rather than institutions. Common measures of concentration are the total percentage of blockholdings with at least three per cent of the equity (UK) or five per cent (US), and the Herfindahl index. These measures of concentration will typically be much lower if the company has several large group holdings where each group has a number of funds. ${ }^{18}$ In addition, the differences in concentration across a sample of companies will be affected. The types of study which might benefit from this approach include studies focused on the behaviour of investing institutions, and on the impact of large shareholders on corporate governance.

\section{CONCLUSION}

This paper examines whether asset-management groups appear to act as a single agent in response to announcements of large takeovers by firms in which the group has more than one fundholding. The paper measures the response by means of the change in the holding of each of the group's funds around the announcement date. In groups with two or three funds with holdings in the relevant company, there is agreement in $69 \%$ of cases using the simple measure, or $54 \%$ using the refined measure. In groups with four or more funds, there is complete or near-complete agreement, i.e. one fund is out of line, in $68 \%$ (simple) or $42 \%$ (refined).

Some of the smaller changes to existing fundholdings might arise for reasons unconnected with news of the takeover. To ameliorate the over-estimation of disagreement that might result from this, we re-run the analysis after filtering out changes of less than $10 \%$, and counting them as 'no change'. The filter increases full agreement from $69 \%$ to $78 \%$ (simple measure), or from $54 \%$ to $59 \%$ (refined measure), for groups with two or three funds. For 
groups with four or more funds, complete or near-complete agreement increases from $68 \%$ to $80 \%$ (simple measure), or from $42 \%$ to $53 \%$ (refined measure).

We conclude that, in funds with four or more holdings, there is, or at least might be, a co-ordinated response in between $42 \%$ and $80 \%$ of cases, depending on how agreement is measured. There is material disagreement in the remaining cases. These latter groups do not appear to have co-ordinated the trading of their fund managers in response to the takeover, and so, by this measure, they do not act in a unified manner. We investigate reasons why trading decisions might differ across funds in a group, other than disagreement across the fund managers in their views of the company/takeover. The net cash flows into or out of the fund have an impact on its trading, and we suspect that other fund- and time-specific reasons can arise.

It might be the case that a given asset-management group sometimes acts in a unified manner towards companies it invests in, but that the takeover announcement in our sample is not considered important enough for the relevant internal mechanism to be made to operate, which would ensure co-ordinated investment decisions across its funds. If this is true, our test for unified action arguably is not powerful. But then we have to wonder what sort of things would be important enough for a group to act in a unified manner, and in what ways the group might seek to do so. For example, perhaps the group does not require its funds to have a common investment policy in response to a takeover or other major event, but it would ensure that all the shares in its holdings vote in the same way, if a takeover were put to an extraordinary general meeting. This would be interesting to explore. ${ }^{19}$

Second, and related to the first point, it might be the case that fund managers typically do not react to announcements of major takeovers by changing their holdings in the company. They may have a view about the takeover, but their view is not captured by the behaviour we observe in this study, i.e. changes in fundholdings. If this is true, then the 'no change' category 
must be larger than it would be were the event one that would elicit more response, and the many changes in holdings that we record must occur for reasons other than the view of the relevant fund manager about the announcement. It would be of interest to investigate further why funds within a group do not co-ordinate their trading decisions around takeovers and to study whether our findings apply to other major corporate events.

In a sense it does not matter whether different decisions among intra-group funds are the result of differences of opinion across the fund managers about the takeover, or of indifference towards the takeover, in which case the holdings must change for other reasons. The point is that, in these cases, trading at the level of the institution is not being used as a corporate governance mechanism, i.e. to influence the managers. Researchers posit a role for institutional shareholders on the basis that they are not merely passive owners of the shares, who are disengaged from the company. A standard example of a hypothesised active role for a blockholder is that the blockholder is in a position to encourage, and will actually encourage, the managers to act in ways which promote shareholder wealth. This could be by means of direct communication with the company or analysts, or by buying (selling) shares in response to news which the blockholder perceives to be good (bad) for market value, or by threatening exit unless management pursues policies approved by the blockholder. Whichever way, the hypothesised mechanism of encouragement assumes that the blockholder acts as a single agent. Our evidence indicates that, in a large minority of cases, institutional blockholders do not coordinate their in-house share dealings in response to news of a strategic nature. In these cases the mechanism of encouragement through share dealing might not happen, because the institution does not act as a single agent.

From a policy perspective, there have been repeated calls for a greater stewardship role on the part of the institutional owners of major companies. This is seen to require greater coordination between investors, for example in the Kay Review (2012). Co-ordination is also 
required between fund managers within an institution. This is an aspect of the challenge of improving stewardship that has been rather overlooked.

Large blockholders and measures of ownership concentration feature across a broad range of research in corporate finance. This paper raises the question of how a block should be defined and identified, for the purposes of research. It would be helpful to know more about how behaviour is co-ordinated in owners, such as asset-management groups and families, where the block will often consist of several holdings managed by different people. To pursue further the question of why differences in trading arise within a group would require better data about the funds in a group, or an interview-based study. 


\section{APPENDIX}

\section{A. Identifying the Owners of Shareholdings ${ }^{20}$}

The share register of a company lists the legal owners, who are also known as the registered owners. Members of the public are entitled to consult share registers. In the case of institutional investors, a holding is normally registered under a nominee name. The registration consists of the name of a nominee company, such as State Street Nominees Ltd, together with an account-designation code, such as HG22. To find out who the beneficial owner is of a given registered holding, the company, or an agent with authorisation to act on behalf of the company, makes an enquiry to the nominee company about the holding, under Section 793 of the Companies Act 2006. ${ }^{21}$ Argus Vickers has been given authorisation by certain UK listed companies to make Section 793 enquiries on their behalf. Other sources of information include reports of changes in holdings of at least three per cent on the Regulatory News Service of the London Stock Exchange, searches of websites via Google, and annual reports (though the holdings disclosed in annual reports are not always accurate).

The reply from a nominee company to a Section 793 enquiry (about the beneficial owner of a holding with a given account designation code) consists of a list of one or more subholdings held in the same nominee account. For each subholding owned or managed by an institutional investor, the reply shows the name of the relevant managed fund and the assetmanagement group of which the fund is a part, with a contact address for the fund, and a separate code for the subholding that is distinct from the nominee company's accountdesignation code. In this process the beneficial owner is treated as the managed fund, rather than the investors in the fund. If a given fund or shareholder has shares registered in more than one nominee account, the total has to be built up from the results of more than one Section 793 enquiry. 
Letters from the company to its shareholders are sent to the registered owners; that is, to nominee companies in the first instance, in the case of institutional holdings. The nominee then forwards the letters to the beneficial owners. An asset-management group with subholdings by $n$ funds will receive $n$ copies of each letter, assuming each fund has one registered holding in the company. The arrangements for how such letters are responded to, including how the shares are voted, vary across asset-management groups. But potentially each fund manager in a given group could respond to letters from companies independently of the other managers. The nature of the control of a specific client's holding can also vary depending on the arrangements made between the client and the group. For example, if a pension fund has awarded a group an investment mandate, the pension fund will presumably allow the group discretion to trade shares, but it might retain control of the voting of those shares. 


\section{B. Sets of decisions by funds for agreement level $\mathrm{C}$ and lower, for groups of four to eight funds, refined measure}

This table shows a selection of the sets of decisions which underlie the agreement levels, using the refined measure, as in Table 3 . The purpose is to show what the various levels of agreement look like in terms of the distribution of decisions. The numbers in each cell are the numbers of funds showing each of the four possible decisions, omitting zeros, and they sum to the total number of funds in the left-hand column. For example, the set '2, 2' means that two of the funds in a group show a decision of one type, such as 'buy', two show a decision of another type, such as 'no change', and no funds show decisions of the remaining two types. Where a cell contains two sets of decisions, both sets produce the same agreement score. For example, the combinations ' $1,1,4$ ' and ' 3,3 ' both produce the agreement score 0.31 .

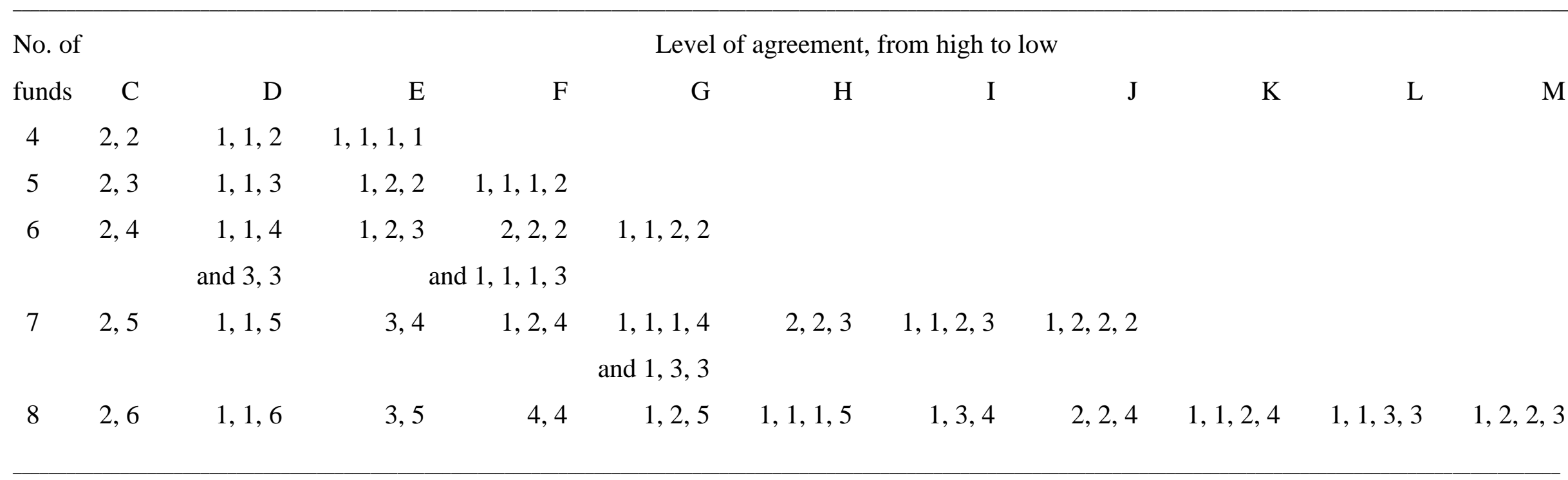




\section{ENDNOTES}

1. The review was sponsored by the UK government and is based on interviews and submitted evidence from practitioners, and existing research. The main conclusions are that professional investors should be less short-termist, and behave more like stewards of the companies they invest in. The review emphasises trying to change the culture of investment, rather than more rules-based regulation.

2. Jenkinson and Jones (2004, pp. 2315-16) write that 'there are two ways of distinguishing between bidders. The first approach treats each bidder with a separate legal identity as distinct. On the other hand, two bidders with different legal identities may represent a single decision maker, in which case the legal entities are merely the portfolios into which the shares are placed after an investment decision has been made. So, XYZ Bank might bid for shares in the name of its European Fund and its Technology Fund, which are distinct legal entities, but the decision-making process might be identical for both. The bookrunner in the data set used in this paper adopted the second approach...' We examine the extent to which this second approach is justified.

3. Some funds are managed by a team of managers, as Ferreira et. al. (2012) also observe. Coordinated behaviour might be more likely in groups where several funds are managed by the same team, or share the same manager. We present evidence below that this is indeed the case, though based on a limited sample.

4. Dlugosz et al. (2006) study the reliability of the information in the Compact Disclosure database about blockholders in US companies, by comparing the CD data with the proxy statements from which the data are derived. The most important error they identify is simple omission of blockholdings. They do not consider whether blocks as recorded in the proxy statement are controlled by a single person or body. 
5. Sometimes two or more holdings registered in different nominee accounts are owned by the same beneficial owner. This happens especially when the name of the beneficial owner is a generic name such as 'Schroder Managed Funds'. In these cases we assume that the total holding is controlled by a single fund manager. This policy probably results in underidentification of individual funds. But we cannot distinguish cases where the separate nominee accounts are present because these are in fact separate funds, controlled by different fund managers, from cases where a single fund is using separate nominee accounts.

6. In these cases trading of the shares might be at the discretion of the individuals concerned, i.e. the shares are not part of a fund controlled by a fund manager.

7. The alternative policy is to ignore the entities and collect all their funds under one group heading, e.g. AXA. This policy would have increased the number of groups with large numbers of holdings, and increased measured disagreement. Entities in the same group include: AXA Financial Inc, AXA Framlington Investment Management, and AXA Investment Management; Barclays Global Investors and Barclays Private Bank; Close Asset Management, Close Finsbury Asset Management, and Close Venture Management Ltd; Credit Suisse and Credit Suisse Asset Management; Deutsche Asset Management and Deutsche Bank AG; Goldman Sachs and Goldman Sachs Asset Management; HSBC Asset Management and HSBC Global Asset Management; Invesco Asset Management and Invesco Aim Capital Management Inc; JPMorgan Asset Management (UK) and JPMorgan Fleming Asset Management.

8. Whitworth and Felton note that their measure is the same as one developed earlier to measure diversity of ecological habitats. We thank Ufuk Guçbilmez for mentioning the WhitworthFelton paper to us.

9. It seems natural to work with a score that is higher when there is more agreement. 10. We also considered measures of herding used in the literature on the investment decisions of mutual funds. The best-known measure is that of Lakonishok, Shleifer and Vishny (1992): 
$H=B /(B+S)-0.5-A F$, where $B$ is the number of funds which buy a given stock over a given period, $S$ is the number which sell, we assume that the probability of a buy with no herding is 0.5 , and $A F$ is an adjustment factor to reflect the fact that, with no herding, $\mathrm{E} \mid B /(B$ $+S)-0.5 \mid>0$. For example, if there are three funds, $A F=0.167$. With no herding, $H=0$. This measure is similar to the simple measure we use. Both assume that only two choices are possible.

11. It is likely that multiple fundholdings within groups have been increasing in recent decades, as a result of the growth in professional investment via specialist funds. For example, since the late 1980s UK pension funds have shifted strongly away from 'balanced mandates', in which all or most of the fund is assigned to a manager who decides on asset allocation as well as security selection. The balanced mandate has been replaced by allocation of the fund to a larger number of specialist managers by asset class and by type of investment within an asset class (Blake et. al., 2013). To meet the demand for more specialist funds, asset-management groups are likely to have increased the supply of such funds.

12. The voting data became available as a result of a requirement of the Securities and Exchange Commission for mutual funds to disclose their votes from 2004. Such voting data are currently limited in the UK but institutions are beginning to provide more detail of their voting behaviour.

13. The full results for this and other tests are available from the authors on request.

14. The expected daily return for each share around the announcement is calculated using the market model. The $\alpha$ and $\beta$ coefficients are calculated using an estimation period of 110 to 10 days prior to the announcement. Our proxy for the market is the Financial Times All-Share Index. The AR we use is the cumulative daily $\mathrm{AR}$ for an event period from day -5 to day +5 , day 0 being the announcement day.

15. For more detail on Morningstar's methodology, see Morningstar (2008). 
16. Excluding index funds reduces agreement after applying the $10 \%$ filter, among groups with four or more funds. The proportion showing agreement levels A or B is $67 \%$ (80\% full sample) using the simple measure, and $48 \%$ (53\%) using the refined measure. This difference arises because the filter reclassifies a much higher proportion of the trades by index funds than by other types of fund as 'no change' (Table 6, Panel A). So the full-sample agreement scores of groups which include index funds are boosted disproportionately by the filter. Excluding the index funds removes the effect of this disproportionate boost.

17. Full results of this test are available from the authors on request.

18. For example, $57.2 \%$ of Bloomsbury Publishing was owned by blockholders each with at least three per cent of the equity after the announcement. Six were groups in our sample, which together owned $43.2 \%$, via 29 separate funds. The remaining three blockholders, not in the sample, owned $14.0 \%$. Only three of the 29 funds within the sample groups had a holding of three per cent or more, and together these three funds owned $14.4 \%$. Thus, on the "proportion owned by blockholders with at least three per cent' measure of concentration, the result is $57.2 \%$ at group level, and $28.4 \%$ at fund or single-agent level.

19. Unfortunately we cannot pursue this at present, because there is no requirement in the UK for the votes of individual shareholders to be disclosed. UK investing institutions are starting to disclose their voting activity (at the level of the institution) on their websites, but the content of what is disclosed varies across institutions. TUC (2013) is a recent survey of institutions about their voting activity.

20. We are grateful to Peter Dewey and Christopher Mangen of Argus Vickers for much of the information in this appendix.

21. See, for example, French, Mayson, and Ryan (annual; pp. 236-9 in the 2008 edition) for an account of the rights of a public company and its shareholders to ascertain who are the beneficial owners of its shares (all listed companies are public companies). Information 
received by a company in response to Section 793 enquiries must be made available to the public for inspection in a register of interests (Section 809). 


\section{REFERENCES}

Becht, M., Franks, J., Mayer, C., and Rossi, S. (2009), 'Returns to shareholder activism: a clinical study of the Hermes UK Focus Fund', Review of Financial Studies 22, pp. 3093-129.

Bharath, S.T, Jayaraman, S. and Nagar, V. (2013), 'Exit as governance: an empirical analysis', Journal of Finance 68, pp. 2515-47.

Blake, D., Rossi, A.G., Timmerman, A., Tonks, I, and Wermers, R. (2013), Decentralized investment management: evidence from the pension fund industry', Journal of Finance 68, pp. 1133-78.

Crespi, R. and Renneboog, L. (2010), 'Is (institutional) shareholder activism new? Evidence from UK shareholder coalitions in the pre-Cadbury era', Corporate Governance: An International Review 18, pp. 274-95.

Crespi-Cladera, R., and Renneboog, L. (2003), 'Corporate monitoring by shareholder coalitions in the UK', European Corporate Governance Institute working paper no. 12/2003.

Dlugosz, J., Fahlenbrach, R., Gompers, P., and Metrick, A. (2006), 'Large blocks of stock: prevalence, size and measurement', Journal of Corporate Finance 12, pp. 594-618.

Edmans, A. (2009), 'Blockholder trading, market efficiency, and managerial myopia', Journal of Finance 64, pp. 2418-2513.

Faccio, M. and Lasfer, M.A. (2000), 'Do occupational pension funds monitor companies in which they hold large stakes?', Journal of Corporate Finance 6, pp. 71-100.

Ferreira, M.A., Keswani, A., Miguel, A.F., and Ramos, S.B. (2013), 'The determinants of mutual fund performance', Review of Finance 17, pp. 483-525.

French, D., Mayson, S.W., and Ryan, C. (2008), Company Law, 25th ed., Oxford University Press. 
Gallagher, D.R, Gardner, P.A. and Swan, P.L. (2013), 'Governance through trading: institutional swing trades and subsequent firm performance', Journal of Financial and Quantitative Analysis 48, pp. 427-58.

Gaspar, J-M., Massa, M., Matos, P., Patgiri, R., and Rehman, Z. (2012), 'Payout policy choices and shareholder investment horizons', Review of Finance 17, pp. 261-320.

Helwege, J., Intintoli, V.J, and Zhang, A. (2012), 'Voting with their feet or activism? Institutional investors' impact on CEO turnover', Journal of Corporate Finance 18, pp. 22-37.

Holderness, C. G. (2009), 'The myth of diffuse ownership in the United States', Review of Financial Studies 22, pp. 1377-1408.

Hovakimian, A. and Li, G. (2010), 'Shareholder investment horizons and payout policy', working paper, ssrn.com/abstract 1571757

Jenkinson, T. and Jones, H. (2004), 'Bids and allocations in European IPO bookbuilding', Journal of Finance 59, pp. 2309- 37.

Kay, J. (2012), Kay Review of UK Equity Markets and Long-Term Decision Making, Final Report, UK Government: www.gov.uk

Lakonishok, J., Shleifer, A., and Vishny, R.W. (1992), 'The impact of institutional trading on stock prices', Journal of Financial Economics 32, pp. 23-43.

McCahery, J.A., Sautner, Z., and Starks, L.T. (2015), 'Behind the scenes: the corporate governance preferences of institutional investors', Journal of Finance, forthcoming.

Moeller, S.B., Schlingemann, F.P., and Stulz, R.M. (2005), 'Wealth destruction on a massive scale? A study of acquiring-firm returns in the recent merger wave', Journal of Finance 60, pp. $757-82$. 
Morgan, A., Pouslen, A., Wolf, J., and Yang, T. (2011), 'Mutual funds as monitors: evidence from mutual fund voting', Journal of Corporate Finance 17, pp. 914-28.

Morningstar (2008), Morningstar Style Box Methodology, Morningstar Inc.

Parrino, R., Sias, R.W., and Starks, L. (2003), 'Voting with their feet: institutional ownership changes around forced CEO turnover', Journal of Financial Economics 68, pp. 3-46.

Sabherwal, S. and Smith, S. D. (2008), 'Concentrated shareholders as substitutes for outside analysts', Corporate Governance: An International Review 16, pp. 562-577.

Tomasic, R., and Akinbami, F. (2013), 'Shareholder activism and litigation against UK banks - the limits of company law and the desperate resort to human rights claims?' in Directors' Duties and Shareholder Litigation in the Wake of the Financial Crisis, Loughrey, J. (ed.), Cheltenham: Edward Elgar, pp. 143-172.

TUC (2013), TUC Fund Manager Voting Survey 2013, Trades Union Congress, tuc.org.uk/sites/default/files/TUC_Fund_Manager_Voting_Survey_2013.pdf

Whitworth, B. and Felton, R. (1999), 'Measuring disagreement in groups facing limited choice problems', The Database for Advances in Information Systems 30, pp. 22-33. 


\section{Figure 1}

Number of group holdings by size of holding

The figure presents a frequency distribution of the shareholdings in the sample at the level of asset-management groups, by size of the holding as a percentage of the shares outstanding in the relevant company. For example, there are 358 holdings which are less than one per cent of the shares outstanding. The total number of group holdings in the sample is 1,453 . Source of shareholdings data for all tables: Argus Vickers Ltd..

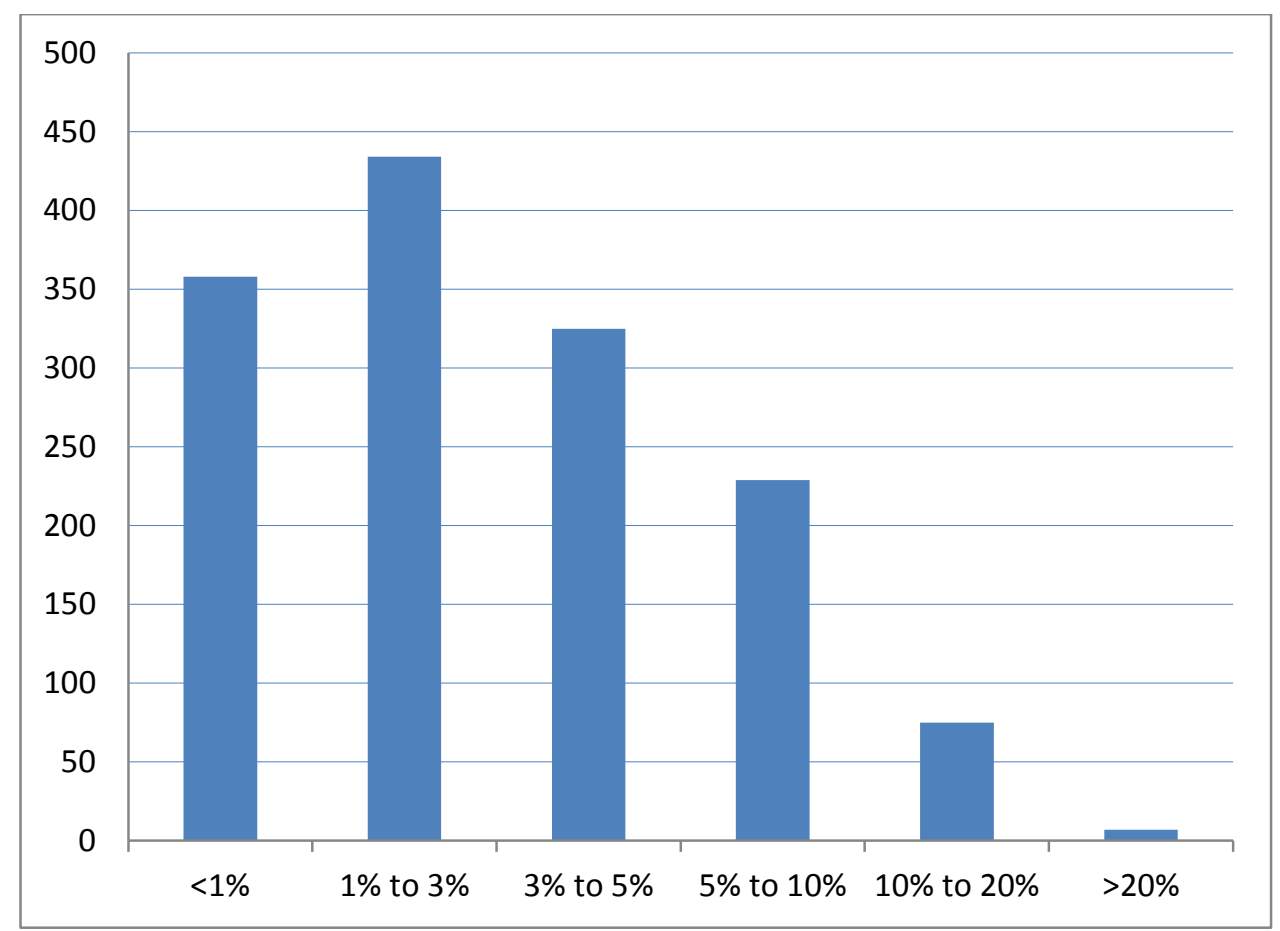


Table 1

Agreement scores for a sample company

The table shows the fund decisions and resulting agreement scores for one of the sample companies. The first column shows the names of groups which have at least two shareholdings in Bloomsbury before or after the takeover announcement by Bloomsbury on 1 July 2009. The next four columns show the number of funds in each group which fall into each of four categories of trading decision. The last two columns show the agreement scores for each group. The choice of a fund under the simple measure is either buy (including no change), or sell, and the agreement score is calculated from equation (1). The choice of a fund under the refined measure is one of the four decisions in columns two to four, and the agreement score is calculated from equation (5).

Bloomsbury Publishing plc

Announcement date: 1 July 2009

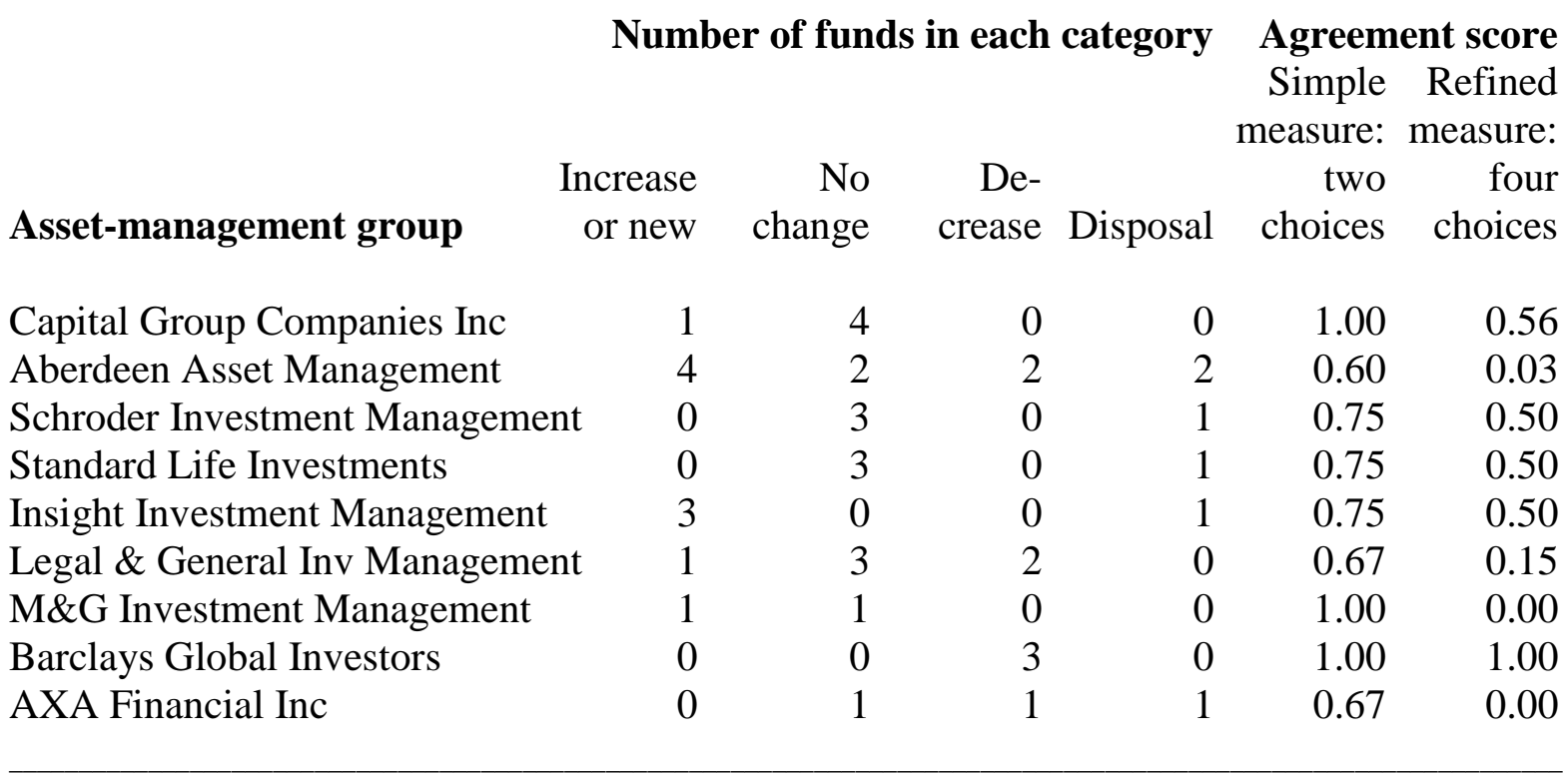


Table 2

\section{Levels of agreement among funds within asset-management groups, using the simple measure of agreement}

Each group shareholding in the sample is the total of the holdings of two or more distinct funds managed within the group. The group holdings are partitioned by the number funds in the group. Each row in the table shows, for the groups with the number of funds per group shown in the first column, the proportion of the groups with each level of agreement (A, B, etc.). The level of agreement is measured from changes in the holdings of funds within a group around the time of a takeover announcement by the relevant company. The table shows results using the simple measure of agreement, in which the choice of a fund is either buy (including no change), or sell. The agreement scores corresponding to each level of agreement are calculated from equation (1). We combine the results for groups with ten or more funds as there is a small number of such groups. For groups with 14 or more funds, which are part of the sample in the last row, there are more possible agreement scores than the number of levels of agreement shown. We omit the levels beyond $\mathrm{G}$ because there are no groups showing disagreement greater than level G.

\begin{tabular}{|c|c|c|c|c|c|c|c|c|}
\hline \multicolumn{9}{|c|}{ Level of agreement, from high to low } \\
\hline Number of funds & A & $\mathrm{B}$ & $\mathrm{C}$ & $\mathrm{D}$ & $\mathrm{E}$ & $\mathrm{F}$ & G & \\
\hline per group & \multicolumn{7}{|c|}{ Percentage of asset-management groups } & No. of groups \\
\hline 2 & $75 \%$ & $25 \%$ & & & & & & 617 \\
\hline 3 & $57 \%$ & $43 \%$ & & & & & & 297 \\
\hline 4 & $42 \%$ & $39 \%$ & $20 \%$ & & & & & 199 \\
\hline 5 & $37 \%$ & $35 \%$ & $28 \%$ & & & & & 124 \\
\hline 6 & $25 \%$ & $33 \%$ & $30 \%$ & $11 \%$ & & & & 79 \\
\hline 7 & $36 \%$ & $32 \%$ & $20 \%$ & $12 \%$ & & & & 50 \\
\hline 8 & $33 \%$ & $26 \%$ & $19 \%$ & $15 \%$ & $7 \%$ & & & 27 \\
\hline 9 & $21 \%$ & $29 \%$ & $21 \%$ & $17 \%$ & $13 \%$ & & & 24 \\
\hline \multirow[t]{2}{*}{10 to 18} & $14 \%$ & $19 \%$ & $28 \%$ & $6 \%$ & $6 \%$ & $25 \%$ & $3 \%$ & 36 \\
\hline & & & & & & & & 1,453 \\
\hline
\end{tabular}


Table 3

Levels of agreement among funds within asset-management groups, using the refined measure of agreement

The table shows the same information as Table 2, but using the refined measure of agreement for the trading decisions of the funds within a given group. Under the refined measure, four decisions are possible rather than two: (i) increase in holding, or new holding, (ii) no change, (iii) decrease, (iv) decrease to zero. The agreement scores corresponding to each level are calculated from equation (5). The table is condensed a little, to reduce the number of columns. There are more possible agreement scores than the number of levels of agreement shown, for groups with seven or more funds. Also, some of the lower levels of agreement correspond to more than one possible score, for these groups.

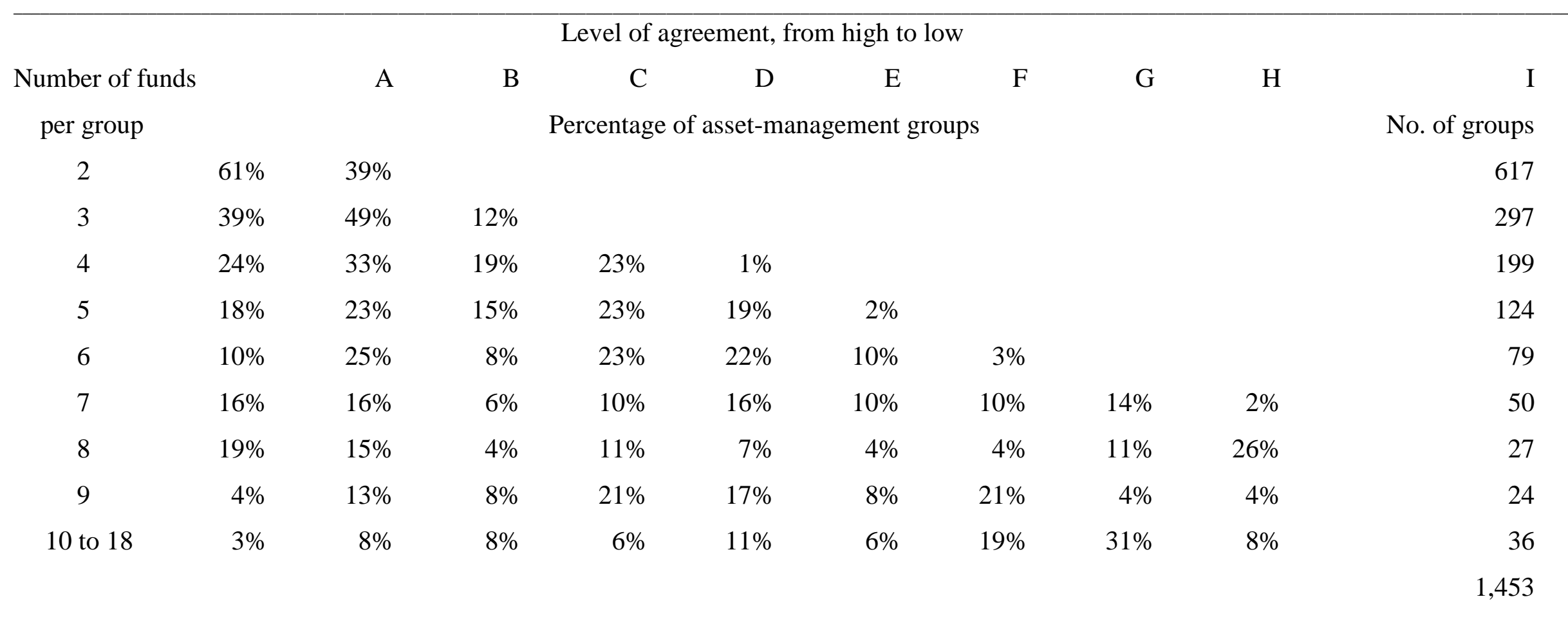


Table 4

\section{Levels of agreement by asset-management group}

This table shows all the groups in the sample with at least five companies in which the group has two or more holdings. The second column shows the proportion of companies for which the group has an agreement score at level A, i.e. full agreement across the funds. The third column shows the number of entries of the group in our sample, i.e. the number of companies for which the group has two or more holdings.

\begin{tabular}{llr}
\hline Asset-management group & $\begin{array}{l}\text { Proportion with } \\
\text { score at level A }\end{array}$ & $\begin{array}{r}\text { Number of } \\
\text { entries }\end{array}$ \\
\hline
\end{tabular}

Aberdeen Asset Managers

$47 \%$

Aberforth Partners

Aegon Asset Management UK

Allchurches Investment Management Services

Allianz Global Investors

Artemis Investment Management LLP

Aviva Investors

AXA Financial Inc

AXA Framlington Investment Management

AXA Investment Managers

Baillie Gifford \& Co

Barclays Global Investors

Blackrock Investment Management

Bluehone Investors LLP

Canada Life

Capital Group Companies Inc

Cazenove Capital Management

Close Venture Management Limited

Columbia Wanger Asset Management

Co-Operative Asset Management

Credit Suisse Asset Management

F\&C Asset Management

Fidelity Investments

Gartmore Investment Management

Grantham Mayo Van Otterloo

Hargreave Hale \& Co

Henderson Global Investors

Hermes Pensions Management

HSBC Asset Management

Insight Investment Management

Invesco Asset Management

JPMorgan Asset Management (UK)

Jupiter Asset Management

Lazard Fund Managers Limited

Legal \& General Investment Management

Liontrust Asset Management

Liverpool Victoria Asset Management

$67 \%$

$43 \% \quad 28$

$80 \% \quad 5$

$63 \% \quad 8$

$68 \% \quad 34$

$37 \% \quad 27$

$38 \% \quad 16$

$67 \% \quad 39$

$56 \% \quad 18$

$67 \% \quad 9$

$25 \% \quad 51$

$57 \% \quad 37$

$80 \% \quad 5$

$91 \% \quad 11$

$54 \% \quad 13$

$80 \% \quad 5$

$100 \% \quad 14$

$80 \% \quad 5$

$63 \% \quad 8$

$55 \% \quad 11$

$47 \% \quad 49$

$49 \% \quad 49$

$63 \% \quad 38$

$56 \% \quad 9$

$91 \% \quad 11$

$40 \% \quad 43$

$71 \% \quad 35$

$50 \% \quad 12$

$67 \% \quad 36$

$58 \% \quad 24$

$45 \% \quad 20$

$93 \% \quad 14$

$60 \% \quad 5$

$26 \% \quad 76$

$83 \% \quad 6$

$88 \% \quad 8$ 


\begin{tabular}{lrr}
\hline Asset-management group & $\begin{array}{c}\text { Proportion with } \\
\text { score at level A }\end{array}$ & $\begin{array}{r}\text { Number of } \\
\text { entries }\end{array}$ \\
\hline M\&G Investment Management & $47 \%$ & 64 \\
Merrill Lynch Investment Management & $83 \%$ & 6 \\
Montanaro Investment Managers & $71 \%$ & 7 \\
Morley Fund Management & $39 \%$ & 56 \\
New Star Asset Management & $63 \%$ & 7 \\
Newton Investment Management & $17 \%$ & 6 \\
Octopus Investments Limited & $100 \%$ & 14 \\
Old Mutual & $73 \%$ & 15 \\
Rathbone Investment Management & $88 \%$ & 16 \\
Royal London Asset Management & $86 \%$ & 14 \\
Schroder Investment Management & $44 \%$ & 43 \\
Scottish Widows Investment Partnership & $50 \%$ & 52 \\
Shell Pensions & $50 \%$ & 8 \\
Singapore Government Investment Corp & $75 \%$ & 12 \\
Slater Investments Limited & $100 \%$ & 6 \\
Standard Life Investments & $33 \%$ & 57 \\
State Street Global Advisers (UK) & $37 \%$ & 19 \\
Threadneedle Asset Management & $69 \%$ & 26 \\
UBS Global Asset Management & $62 \%$ & 13 \\
Unicorn Asset Management & $65 \%$ & 17 \\
\hline
\end{tabular}




\section{Table 5}

\section{Levels of agreement among funds within asset-management groups, after $10 \%$ filter on changes, simple measure}

The table shows the same information as Table 2, except that the simple agreement score for each group is calculated after making the following alteration to the decisions of the funds: changes in existing holdings of less than $10 \%$ of the holding are counted as 'no change'. This means that small trades in relation to the existing holding are not counted as trades. New holdings and complete disposals are unaffected and remain in the sample. We combine the results for groups with ten or more funds as there is a small number of such groups. For groups with 14 or more funds, there are more possible agreement scores than the number of levels of agreement shown. We omit the levels beyond $\mathrm{G}$ because there are no groups showing disagreement greater than level G.

\begin{tabular}{|c|c|c|c|c|c|c|c|c|}
\hline \multicolumn{9}{|c|}{ Level of agreement, from high to low } \\
\hline Jumber of funds & A & $\mathrm{B}$ & $\mathrm{C}$ & $\mathrm{D}$ & $\mathrm{E}$ & $\mathrm{F}$ & $\mathrm{G}$ & \\
\hline per group & \multicolumn{7}{|c|}{ Percentage of asset-management groups } & No. of groups \\
\hline 2 & $82 \%$ & $18 \%$ & & & & & & 617 \\
\hline 3 & $70 \%$ & $30 \%$ & & & & & & 297 \\
\hline 4 & $60 \%$ & $30 \%$ & $10 \%$ & & & & & 199 \\
\hline 5 & $53 \%$ & $30 \%$ & $17 \%$ & & & & & 124 \\
\hline 6 & $38 \%$ & $35 \%$ & $16 \%$ & $10 \%$ & & & & 79 \\
\hline 7 & $52 \%$ & $26 \%$ & $16 \%$ & $6 \%$ & & & & 50 \\
\hline 8 & $41 \%$ & $37 \%$ & $19 \%$ & $4 \%$ & $0 \%$ & & & 27 \\
\hline 9 & $33 \%$ & $21 \%$ & $8 \%$ & $25 \%$ & $13 \%$ & & & 24 \\
\hline \multirow[t]{2}{*}{10 to 18} & $22 \%$ & $22 \%$ & $28 \%$ & $22 \%$ & $0 \%$ & $3 \%$ & $3 \%$ & 36 \\
\hline & & & & & & & & 1,453 \\
\hline
\end{tabular}




\section{Table 6}

\section{Levels of agreement among funds within asset-management groups, after $10 \%$ filter on changes, refined measure}

The table shows the same information as Table 3, except that the refined agreement score for each group is calculated after making the following alteration to the decisions of the funds: changes in existing holdings of less than $10 \%$ of the holding are counted as 'no change'. This means that small trades in relation to the existing holding are not counted as trades. New holdings and complete disposals are unaffected and remain in the sample. The table is condensed a little, to reduce the number of columns. There are more possible agreement scores than the number of levels of agreement shown, for groups with seven or more funds. Also, some of the lower levels of agreement correspond to more than one possible score, for these groups.

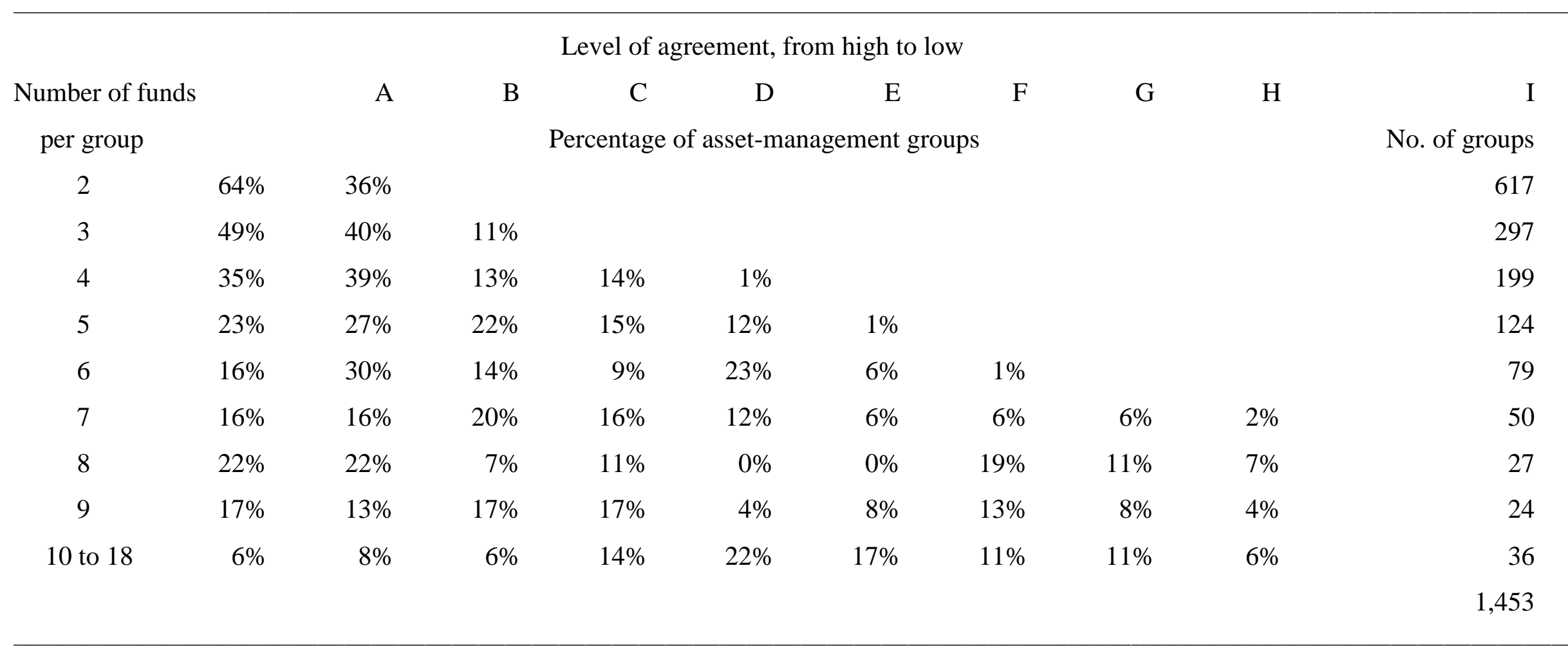


Table 7

\section{Robustness checks: abbreviated results for various subsamples}

The agreement measures are calculated for subsamples after excluding (i) index funds, (ii) funds which do not trade, (iii) announcements where the equity plus debt of the company acquired is less than $30 \%$ of the market capitalisation of the acquiring company, and for subsamples where the market reaction to the announcement was (iv) positive and (v) negative. The market reaction is the three-day market-adjusted return on the acquirer's shares, centred on the announcement day. The summary measures shown are the proportion of groups with agreement levels A (all funds in the group make the same decision), for groups with two or three funds, and the proportion with levels A or B (only one fund is out of line), for groups with four or more funds. Equivalent results for the full sample are shown in the last column for ease of comparison. The numbers of groups in (i) to (iii) are smaller than the number in the full sample because exclusions of funds leave some groups with fewer than two funds. The sums of the groups in (iv) and (v) is slightly less than the number in the full sample because we were unable to calculate a market reaction for a few companies, due to missing price data. $* *=$ different from the comparable result for the full sample at the $1 \%$ level of significance.

Proportion of groups with agreement level A for 2 or 3 funds in group, and A or B for 4 or more funds

(i)

Excluding index funds (ii)
Excluding

funds with

no trade (iii)

Excluding

takeovers

$<30 \%$ (iv)

Takeovers with positive mkt reaction
Full

Takeovers with negative mkt reaction sample (v)$$
\text { ) }
$$

2 or 3 funds in group

Simple measure

Refined measure

$$
69 \%
$$

$53 \%$

4 or more funds

Simple measure

Refined measure

$70 \%$

$46 \%$

$63 \%$
$59 \%$
$69 \%$
$65 \% * *$

$72 \%$

$58 \%$

$72 \%$

$54 \%$

$67 \%$

$44 \%$

981

686

$66 \%$

$51 \%$

$65 \%$

$36 \%$

598

Number of groups in subsample 1,383

$46 \%$

830

$69 \%$

$54 \%$

$68 \%$

$42 \%$

1,453 


\section{Table 8 \\ Fund styles and trading decisions}

The table shows results of an analysis of trading decisions in relation to the investment style of the fund. Index, value, growth and neutral styles are as given by Morningstar. We record the style for the month of the announcement, or if not reported, for the most recent of the preceding six months. Pension funds with 'balanced', 'managed', or 'with profits' in the name are counted as neutral. In addition, we create a venture capital trust category based on the names of funds. The 'unidentified' category consists of funds which are not given any of the above classifications, or for which there are no Morningstar data. Panel A shows the proportion of the funds in each style category that traded around the takeover decision. Panel B shows the proportion in each style category that made each of the four possible trading decisions. * $(* *)$ $=$ difference between the proportion for the style and the proportion for the rest of the sample is significant at the 5\% (1\%) level.

\section{Panel A}

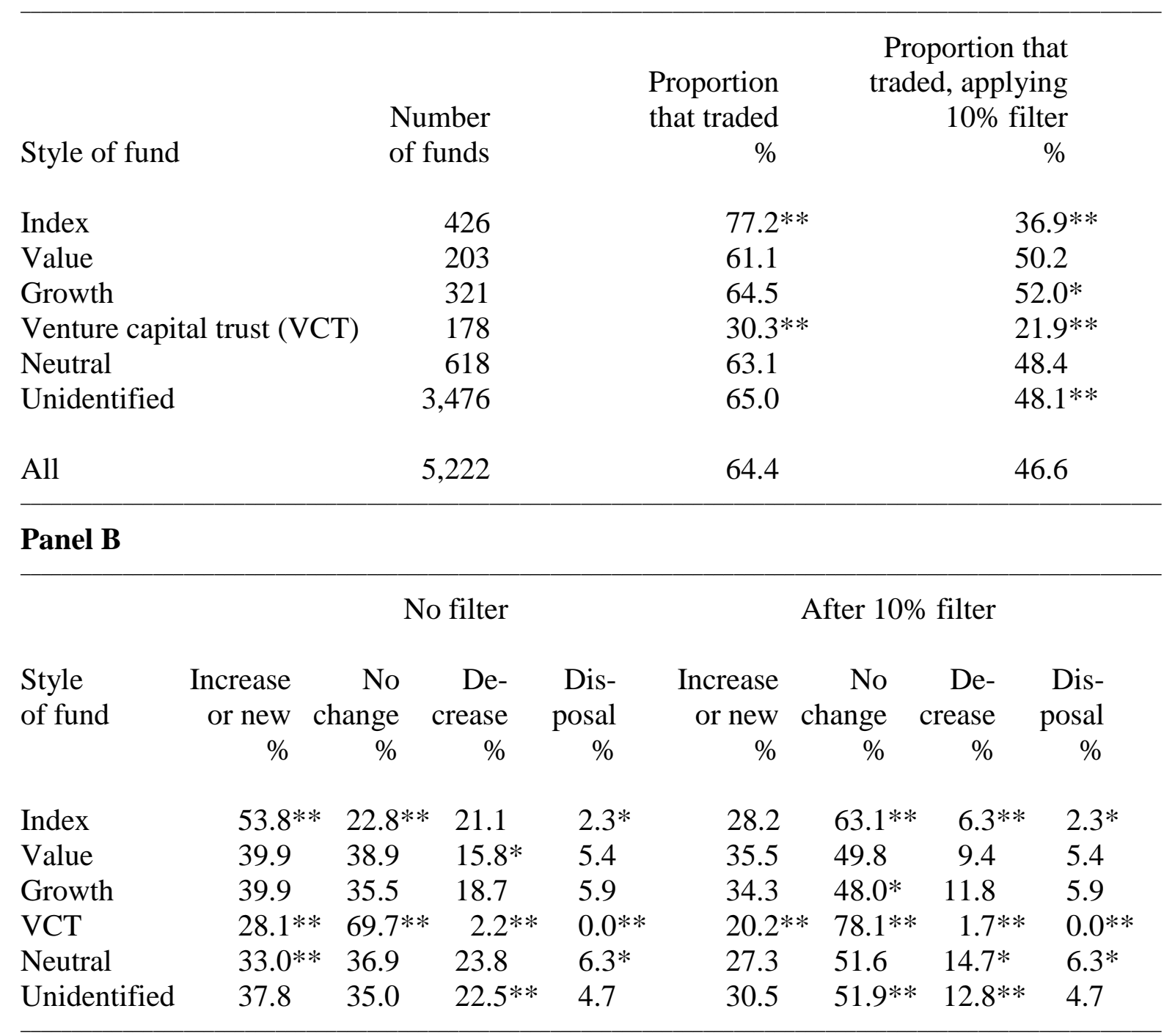


Table 9

Fund cash flows and trading decisions

Monthly net cash flows into or out of a given fund are summed for the months over which we measure the change in its holding of a sample company. The funds are partitioned by the sign of the cumulative net cash flows. The table shows the proportion of funds with positive or negative net flows which do not trade and which have an increased or new holding (a positive trade). The value of funds is measured as at the start of the period over which the cash flows are measured. $*(* *)=$ difference between the proportions of funds with positive trades between funds with positive and negative flows is significant at the 5\% (1\%) level. Source of data: Morningstar.

Funds with positive net flows

All funds with positive flows

Excluding funds with flows/value $<2 \%$

Excluding funds with flows/value $<5 \%$

Excluding funds with flows/value $<10 \%$

\section{No filter}

No trade $\% \quad$ Positive $\%$

\section{7}

37.2

37.2

31.3

36.7

Funds with negative net flows

All funds with negative flows

Excluding funds with flows/value $<2 \%$

Excluding funds with flows/value $<5 \%$

Excluding funds with flows/value $<10 \%$

\section{Positive \%}

\section{4}

51.6

52.0

57.5

$38.3^{*}$
$37.5^{* *}$
$33.6^{* *}$
$28.2^{* *}$

After $10 \%$ filter

No trade $\% \quad$ Positive $\%$

53.5

51.6

38.5

41.7

43.2

51.3

40.0

52.8

32.0

$31.6^{*}$

$29.0^{*}$

52.0
49.6

38.5

\section{$\mathrm{N}$}

325

223

148

80

447

275

131 


\section{Table 10 \\ Regressions to explain agreement}

The table shows the results of logit regressions. The dependent variable is equal to one if the funds in an asset-management group show full agreement (level A) in their trading decisions, and zero otherwise. The four models use different measures of full agreement. Nfunds= number of funds in a given group; Relbidsize = market capitalisation of target company plus debt divided by market capitalisation of acquiring company, measured four weeks before the announcement; Mreaction = three-day market-adjusted return on the acquirer's shares, centred on the announcement day; Mcap $=\ln$ market capitalisation of the acquiring company. ${ }^{*}(* *)=$ significant at the 5\% (1\%) level.

\begin{tabular}{|c|c|c|c|c|}
\hline & \multicolumn{2}{|c|}{ Before $10 \%$ filter } & \multicolumn{2}{|c|}{ After $10 \%$ filter } \\
\hline & $\begin{array}{l}\text { 1. Simple } \\
\text { measure }\end{array}$ & $\begin{array}{l}\text { 2. Refined } \\
\text { measure }\end{array}$ & $\begin{array}{l}\text { 3. Simple } \\
\text { measure }\end{array}$ & $\begin{array}{l}\text { 4. Refined } \\
\text { measure }\end{array}$ \\
\hline Nfunds & $\begin{array}{l}-0.389 * * \\
0.036\end{array}$ & $\begin{array}{l}-0.577^{* *} \\
0.049\end{array}$ & $\begin{array}{c}-0.308^{* *} \\
0.031\end{array}$ & $\begin{array}{c}-0.498 * * \\
0.043\end{array}$ \\
\hline Relbidsize & $\begin{array}{l}0.334^{*} \\
0.166\end{array}$ & $\begin{array}{l}0.120 \\
0.163\end{array}$ & $\begin{array}{r}-0.041 \\
0.163\end{array}$ & $\begin{array}{r}-0.122 \\
0.157\end{array}$ \\
\hline Mreaction & $\begin{array}{l}0.493 \\
0.430\end{array}$ & $\begin{array}{l}1.28^{* * *} \\
0.484\end{array}$ & $\begin{array}{l}0.464 \\
0.439\end{array}$ & $\begin{array}{l}0.722 \\
0.439\end{array}$ \\
\hline Mcap & $\begin{array}{c}-0.226^{* *} \\
0.033\end{array}$ & $\begin{array}{c}-0.200^{* *} \\
0.034\end{array}$ & $\begin{array}{c}-0.123 * * \\
0.034\end{array}$ & $\begin{array}{c}-0.171^{* *} \\
0.033\end{array}$ \\
\hline Constant & $\begin{array}{l}2.957 * * \\
0.282\end{array}$ & $\begin{array}{l}2.730^{* *} \\
0.298\end{array}$ & $\begin{array}{l}2.703^{* *} \\
0.281\end{array}$ & $\begin{array}{l}2.672 * * \\
0.285\end{array}$ \\
\hline$N$ & 1,299 & 1,299 & 1,299 & 1,299 \\
\hline Pseudo $R^{2}$ & 0.12 & 0.15 & 0.08 & 0.13 \\
\hline
\end{tabular}

